\title{
Simulated Effects of Year 2030 Water-Use and Land-Use Changes on Streamflow near the Interstate-495 Corridor, Assabet and Upper Charles River Basins, Eastern Massachusetts
}

By Carl S. Carlson, Leslie A. DeSimone, and Peter K. Weiskel

Prepared in cooperation with the

Metropolitan Area Planning Council

Scientific Investigations Report 2008-5132 


\section{U.S. Department of the Interior DIRK KEMPTHORNE, Secretary}

\section{U.S. Geological Survey \\ Mark D. Myers, Director}

\section{U.S. Geological Survey, Reston, Virginia: 2008}

For product and ordering information:

World Wide Web: http://www.usgs.gov/pubprod

Telephone: 1-888-ASK-USGS

For more information on the USGS--the Federal source for science about the Earth, its natural and living resources, natural hazards, and the environment:

World Wide Web: http://www.usgs.gov

Telephone: 1-888-ASK-USGS

Any use of trade, product, or firm names is for descriptive purposes only and does not imply endorsement by the U.S. Government.

Although this report is in the public domain, permission must be secured from the individual copyright owners to reproduce any copyrighted materials contained within this report.

Suggested citation:

Carlson, C.S., DeSimone, L.A., Weiskel, P.K., 2008, Simulated effects of year 2030 water-use and land-use changes on streamflow near the Interstate-495 corridor, Assabet and Upper Charles River Basins, eastern Massachusetts:

U.S. Geological Survey Scientific Investigations Report 2008-5132, 108 p. 


\section{Contents}



2030 Simulated Streamflows for Habitat Requirements....................................................................29

Assessment of Potential Effects of Low-Impact Development in Hop Brook Subbasin, Assabet

River Basin-A Test Case .....................................................................................................36

Assessment of Potential Effects of Sewering in Fort Pond Brook Subbasin, Assabet River

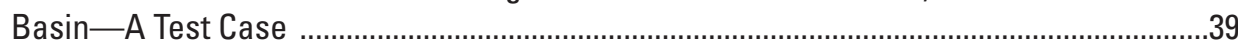

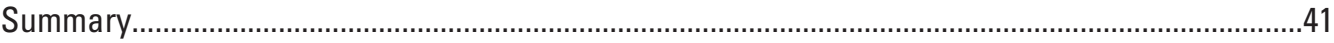

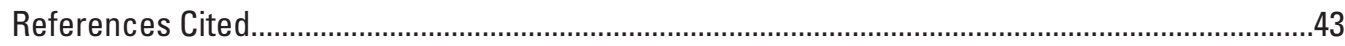

Appendix 1. Methods Used to Develop Input Files for 2030 Model Scenarios ..............................45

Appendix 2. Year 2030 monthly ground-water and surface-water withdrawals, Zone II limits for wells or the maximum withdrawal limit used for surface sources, Assabet and Upper Charles River basins, eastern Massachusetts.

Appendix 3. Changes in average-annual water-budget inflows and outflows from basecase conditions for the seven scenarios by subbasin, Assabet River Basin, eastern Massachusetts

Appendix 4. Changes in March and September water-budget inflows and outflows from basecase for seven scenarios, by subbasin, Assabet River Basin, eastern Massachusetts

Appendix 5. Changes in average annual water budget inflows and outflows from basecase for seven scenarios, by subbasin, Upper Charles River Basin, eastern Massachusetts

Appendix 6. Changes in March and September water-budget inflows and outflows from basecase for seven scenarios, by subbasin, Upper Charles River basin, eastern Massachusetts 


\section{Figures}

1-3. Maps showing-

1. Location of subbasins and points of simulated streamflow comparison for (A) Assabet River Basin (1997-2001) and (B) Upper Charles River Basin (1989-98), eastern Massachusetts . .3

2. Developable land areas and surficial geology in $(A)$ Assabet and (B) Upper Charles River Basins, eastern Massachusetts... .8

3. Locations of subbasin and year 2030 new-development areas in (A) Assabet River Basin and (B) Upper Charles River Basin, eastern Massachusetts. 10

4-12. Graphs showing-

4. Change in simulated average-annual cumulative downstream streamflow from simulated basecase conditions for seven scenarios for Assabet River Main Stem subbasins, eastern Massachusetts

5. Change in simulated average-annual streamflow from simulated basecase conditions for seven scenarios for individual subbasins in the Assabet River Basin, eastern Massachusetts.

6. Change in simulated cumulative downstream streamflow from simulated basecase conditions for seven scenarios in (A) March and (B) September for Assabet River Main Stem subbasins, eastern Massachusetts

7. Change in simulated streamflow from simulated basecase conditions for seven scenarios in (A) March and (B) September for individual subbasins in the Assabet River Basin, eastern Massachusetts.

8. Change in simulated average-annual cumulative downstream streamflow from simulated basecase conditions for seven scenarios for Upper Charles River Main Stem subbasins, eastern Massachusetts

9. Change in simulated average-annual streamflow from simulated basecase conditions for seven scenarios for individual subbasins in the Upper Charles River Basin, eastern Massachusetts.

10. Change in simulated cumulative downstream streamflow from simulated basecase conditions for seven scenarios in (A) March and (B) September for Upper Charles River Main Stem subbasins, eastern Massachusetts

11. Change in simulated streamflow from simulated basecase conditions for seven scenarios in $(A)$ March and $(B)$ September for individual subbasins in the Upper Charles River Basin, eastern Massachusetts.

12. Percentage of simulated streamflow out of $(A)$ Assabet and $(B)$ Upper Charles River Main Stem subbasins that is simulated wastewater-treatment facility (WWTF) discharge for basecase and seven scenarios, eastern Massachusetts.

13-22. Graphs showing-

13. Greatest percentage change in simulated streamflow from basecase conditions for seven scenarios in (A) Assabet River and (B) Upper Charles River subbasins, eastern Massachusetts.

14. Simulated mean monthly nonstorm streamflows for $(A)$ March and (B) September for seven scenarios and basecase conditions and the portion that originated as wastewater, Assabet River Basin, eastern Massachusetts......30

15. Simulated mean monthly nonstorm streamflows for $(A)$ March and (B) September for seven scenarios and basecase conditions and the portion that originated as wastewater, total nonstorm streamflow and the component of streamflow that originated as wastewater Upper Charles River Basin, eastern Massachusetts. 
16. Changes in simulated mean monthly nonstorm streamflows for $(A)$ March and $(B)$ September from basecase conditions for seven scenarios for subbasins in the Assabet River Basin, eastern Massachusetts.

17. Changes in simulated mean monthly nonstorm streamflows for $(A)$ March and (B) September from basecase conditions for seven scenarios for subbasins in the Upper Charles River Basin, eastern Massachusetts.

18. Simulated mean monthly streamflows in cubic feet per second per square mile for (A) March and (B) September for seven scenarios and basecase conditions for individual subbasins in the Assabet River Basin, eastern Massachusetts .......34

19. Simulated mean monthly streamflows in cubic feet per second per square mile for ( $A$ ) March and (B) September for seven scenarios and basecase conditions for individual subbasins in the Upper Charles River Basin, eastern Massachusetts

20. Simulated cumulative downstream streamflow in cubic feet per second per square mile for $(A)$ March and (B) September for seven scenarios and basecase conditions for Main Stem subbasins in the Assabet River Basin, eastern Massachusetts

21. Simulated cumulative downstream in cubic feet per second per square mile streamflow for ( $A$ ) March and (B) September for seven scenarios and basecase conditions for Main Stem subbasins in the Upper Charles River Basin, eastern Massachusetts

22-23. Maps showing-

22. Areas of developable residential and commercial land using low-impact development (LID) practices, Hop Brook subbasin and vicinity, Assabet River Basin, eastern Massachusetts.

23. Acton sewered areas, areas of potential sewering, and wastewater-treatment facility discharge points, Fort Pond Brook subbasin, Assabet River Basin, eastern Massachusetts

\section{Tables}

1. Area available for development and area predicted to be developed by 2030 in subbasins of the Assabet and Upper Charles River Basins, eastern Massachusetts....12

2. Changes in simulated monthly average wastewater discharge for each year 2030 scenario of water-use change from basecase conditions, Assabet River Basin, eastern Massachusetts

3. Changes in simulated monthly average March and September streamflow and cumulative downstream streamflow from basecase conditions for subbasins in the Assabet River Basin, eastern Massachusetts.

4. Changes in simulated monthly average wastewater discharge from basecase conditions for main-stem subbasins, Upper Charles River Basin, eastern Massachusetts....26

5. Changes in simulated monthly average March and September streamflow and cumulative downstream streamflow from basecase conditions for subbasins in the Upper Charles River Basin, eastern Massachusetts.

6. Change in simulated average monthly March and September base flow streamflow between areas of low-impact development (LID) and of traditional development and change between base flow simulated for two scenarios and basecase conditions, Hop Brook subbasin, Assabet River Basin, eastern Massachusetts 


\section{Conversion Factors, Vertical Datum, and other Abbreviations}

\begin{tabular}{|c|c|c|}
\hline Multiply & By & To obtain \\
\hline \multicolumn{3}{|c|}{ Length } \\
\hline foot $(\mathrm{ft})$ & 0.3048 & meter $(\mathrm{m})$ \\
\hline mile (mi) & 1.609 & kilometer (km) \\
\hline \multicolumn{3}{|c|}{ Area } \\
\hline acre & 4,047 & square meter $\left(\mathrm{m}^{2}\right)$ \\
\hline square mile $\left(\mathrm{mi}^{2}\right)$ & 2.590 & square kilometer $\left(\mathrm{km}^{2}\right)$ \\
\hline \multicolumn{3}{|c|}{ Volume } \\
\hline gallon (gal) & 0.003785 & cubic meter $\left(\mathrm{m}^{3}\right)$ \\
\hline million gallons (Mgal) & 3,785 & cubic meter $\left(\mathrm{m}^{3}\right)$ \\
\hline \multicolumn{3}{|c|}{ Flow rate } \\
\hline cubic foot per second $\left(\mathrm{ft}^{3} / \mathrm{s}\right)$ & 0.02832 & cubic meter per second $\left(\mathrm{m}^{3} / \mathrm{s}\right)$ \\
\hline $\begin{array}{l}\text { cubic foot per second per square } \\
\text { mile }\left[\left(\mathrm{ft}^{3} / \mathrm{s}\right) / \mathrm{mi}^{2}\right]\end{array}$ & 0.01093 & $\begin{array}{l}\text { cubic meter per second per square kilometer } \\
\qquad\left[\left(\mathrm{m}^{3} / \mathrm{s}\right) / \mathrm{km}^{2}\right]\end{array}$ \\
\hline gallon per minute (gal/min) & 0.06309 & liter per second $(\mathrm{L} / \mathrm{s})$ \\
\hline gallon per day (gal/d) & 0.003785 & cubic meter per day $\left(\mathrm{m}^{3} / \mathrm{d}\right)$ \\
\hline million gallons per day (Mgal/d) & 0.04381 & cubic meter per second $\left(\mathrm{m}^{3} / \mathrm{s}\right)$ \\
\hline inch per year (in/yr) & 25.4 & millimeter per year (mm/yr) \\
\hline
\end{tabular}

Vertical coordinate information is referenced to the North American Vertical Datum of 1988 (NAVD 88).

*Transmissivity: The standard unit for transmissivity is cubic foot per day per square foot times foot of aquifer thickness [(ft $\left.\left.\mathrm{ft}^{3} / \mathrm{d}\right) / \mathrm{ft}^{2}\right] \mathrm{ft}$. In this report, the mathematically reduced form, foot squared per day $\left(\mathrm{ft}^{2} / \mathrm{d}\right)$, is used for convenience.

$\begin{array}{ll}\text { CRPCD } & \text { Charles River Pollution Control District } \\ \text { GIS } & \text { Geographic information system } \\ \text { LID } & \text { Low-impact development } \\ \text { MAPC } & \text { Metropolitan Area Planning Council } \\ \text { MADEP } & \text { Massachusetts Department of Environmental Protection } \\ \text { MTF } & \text { Milford Treatment Facility } \\ \text { MWL } & \text { Maximum withdrawal limit } \\ \text { MWRA } & \text { Massachusetts Water Resources Authority } \\ \text { TAC } & \text { Technical Advisory Committee } \\ \text { USGS } & \text { U.S. Geological Survey } \\ \text { WWTF } & \text { Wastewater-treatment facility }\end{array}$




\title{
Simulated Effects of Year 2030 Water-Use and Land-Use Changes on Streamflow near the Interstate-495 Corridor, Assabet and Upper Charles River Basins, Eastern Massachusetts
}

\author{
By Carl S. Carlson, Leslie A. DeSimone, and Peter K. Weiskel
}

\section{Abstract}

Continued population growth and land development for commercial, industrial, and residential uses have created concerns regarding the future supply of potable water and the quantity of ground water discharging to streams in the area of Interstate 495 in eastern Massachusetts. Two ground-water models developed in 2002-2004 for the Assabet and Upper Charles River Basins were used to simulate water supply and land-use scenarios relevant for the entire Interstate- 495 corridor. Future population growth, water demands, and commercial and residential growth were projected for year 2030 by the Metropolitan Area Planning Council. To assess the effects of future development on subbasin streamflows, seven scenarios were simulated by using existing computerbased ground-water-flow models with the data projected for year 2030 .

The scenarios incorporate three categories of projected 2030 water- and land-use data: (1) 2030 water use, (2) 2030 land use, and (3) a combination of 2030 water use and 2030 land use. Hydrologic, land-use, and water-use data from 1997 through 2001 for the Assabet River Basin study and 1989 through 1998 for the Upper Charles River Basin study were used to represent current conditions-referred to as "basecase" conditions - in each basin to which each 2030 scenario was compared.

The effects of projected 2030 land- and water-use change on streamflows in the Assabet River Basin depended upon the time of year, the hydrologic position of the subbasin in the larger basin, and the relative areas of new commercial and residential development projected for a subbasin. Effects of water use and land use on streamflow were evaluated by comparing average monthly nonstorm streamflow (base flow) for March and September simulated by using the models. The greatest decreases in streamflow (up to 76 percent in one subbasin), compared to the basecase, occurred in September, when streamflows are naturally at their lowest level. By contrast, simulated March streamflows decreased less than 6.5 percent from basecase streamflows in all subbasins for all scenarios.
The simulations showed similar effects in the Upper Charles River Basin, but increased water use contributed to decreased simulated streamflow in most subbasins. Simulated changes in March streamflows for 2030 in the Upper Charles River Basin were within \pm 6 percent of the basecase for all scenarios and subbasins. Percentage decreases in simulated September streamflows for 2030 were greater than in March but less than the September decreases that resulted for some subbasins in the Assabet River Basin. Only two subbasins of the Upper Charles River Basin had projected decreases greater than 5 percent. In the Mill River subbasin, the decrease was 11 percent, and in the Mine Brook subbasin, 6.6 percent.

Changes in water use and wastewater return flow generally were found to have the greatest effect in the summer months when streamflow and aquifer recharge rates are low and water use is high. September increases in main-stem streamflow of both basins were due mainly to increased discharge of treated effluent from wastewater-treatment facilities on the main-stem rivers. In the Assabet River Basin, wastewater-treatment-facility discharge became a smaller proportion of total streamflow with distance downstream. In contrast, wastewater-treatment facility discharge in the Upper Charles River Basin became a greater proportion of streamflow with distance downstream.

The effects of sewer-line extension and low-impact development on streamflows in two different subbasins of the Assabet River Basin also were simulated. The result of extending sewer lines with a corresponding decrease in septicsystem return flow caused September streamflows to decrease as much as 15 percent in the Fort Pond Brook subbasin. The effect of low-impact development was simulated in the Hop Brook subbasin in areas projected for commercial development. In this simulation, the greater the area where low-impact development practices were applied, the less was the overall effect of development on recharge and nonstorm streamflow compared to the effects of traditional development practices for commercial areas. Low-impact development practices applied to individual parcels can potentially increase recharge in that parcel and consequently have a small effect on nonstorm streamflow out of the subbasin compared to lower 
recharge and nonstorm streamflows usually associated with traditional development practices in commercial areas. If lowimpact development (as defined in this study) is applied to a greater number of surrounding parcels, however, the increase in recharge is additive with a correspondingly greater increase in nonstorm streamflow out of the subbasin compared to the effects on recharge and nonstorm streamflow associated with traditional development practices.

\section{Introduction}

The communities along the Interstate-495 (I-495) corridor in eastern Massachusetts (figs. 1A and 1B) are experiencing commercial, industrial, and residential growth. This growth has generated increased demand for water supply and wastewater disposal. Population growth from 1990 to 2000 averaged 15 percent across the region, but some communities in the region have grown by more than 30 percent (DeSimone, 2004). Continued growth, driven by the technology-based economy of the I-495 area, is expected in the coming decades. In river basins along the I-495 corridor, ground water is withdrawn for municipal supply from the glacial aquifers along the tributaries and main-stem rivers. Because these aquifers are in direct hydraulic connection with surface waters, the withdrawals typically reduce ground-water discharge to streams and wetlands and deplete streamflow (DeSimone, 2004; DeSimone and others, 2002; Eggleston, 2004).

To provide a better description of the effects of water withdrawals and wastewater discharges on streamflow in the basins of eastern Massachusetts, the U.S. Geological Survey (USGS), in cooperation with the Massachusetts Executive Office of Environmental Affairs, Massachusetts Department of Conservation and Recreation, and the Massachusetts Department of Environmental Protection, completed groundwater studies of the Assabet River Basin (DeSimone, 2004) and the Upper Charles River Basin (DeSimone and others 2002; Eggleston, 2004). In the initial studies, scenarios were simulated to evaluate various ground-water management alternatives, analyze discharges at hypothetical sites, and to estimate optimal withdrawals, discharges, and streamflow depletion. The steady-state and transient computer models of ground-water flow developed for these studies form the basis for the study described in this report.

The purpose of the present study, conducted in cooperation with the Metropolitan Area Planning Council (MAPC), was to evaluate the effects of specific waterand land-use scenarios on subbasin streamflow by using data projected for the year 2030. The data and scenarios were implemented in the existing ground-water models of the Assabet and Upper Charles River Basins. The scenarios, which used data projected for year 2030 and applied the data similarly to each of the models, were built upon scenarios already described in DeSimone (2004),
DeSimone and others (2002), and Eggleston (2004). Hydrologic, land-use, and water-use data from 1997 through 2001 for the Assabet River Basin study area and from 1989 through 1998 for the Upper Charles River Basin study area represent the current conditions, referred to as "basecase" conditions, in each basin. To ensure that this study addressed concerns for year 2030 water- and land-use in the basins, representatives from Federal agencies, communities, and other organizations participated in a Technical Advisory Committee (TAC) for this study.

The major goal of this study was to estimate changes in streamflow in each subbasin in the Assabet River Basin and Upper Charles River Basin that would result from water- and land-use conditions projected for 2030. Changes in streamflow from the basecase for each scenario were used to evaluate scenario results. Projected increases in withdrawals would be expected to cause depletion of streamflows, whereas projected increases in return flows would be expected to augment streamflows. Changes in land use projected for year 2030 could cause changes in the rates of precipitation recharge that would ultimately cause changes in streamflow. For results to be comparable between the river basins, changes in recharge were applied to each model in the same manner. The basecase and scenario simulations then were compared to determine the magnitude of change in streamflow in each subbasin within the study areas.

\section{Purpose and Scope}

This report describes the seven scenarios used with available steady-state and transient ground-water models to determine the effects of projected year 2030 water use and land use on streamflow in 22 subbasins. Changes from basecase conditions in land use and water use for year 2030, simulated recharge, and simulated streamflows from each subbasin annually and for March and September are presented, as well as graphs of simulated streamflows for habitat requirements. Finally, the regional ground-water model was used to simulate the potential effects of low-impact development on nonstorm streamflow in one subbasin where future commercial development is likely and of extending sewer lines in another subbasin. These simulations were intended to provide test cases for the applicability of a regional ground-water model to subbasin-specific changes in land use and infrastructure. Results of the low-impact development and sewered area simulations may be applicable to other subbasins as well.

\section{Previous Modeling Studies}

The Assabet River and Upper Charles River Basin studies used computer models of ground-water flow to represent numerically the geologic and hydrologic characteristics of each river basin (DeSimone, 2004; DeSimone and others, 2002; Eggleston, 2004). Both models were based on the 




Figure 1. Location of subbasins and points of simulated streamflow comparison for (A) Assabet River Basin (1997-2001) and (B) Upper Charles River Basin (1989-98), eastern Massachusetts. 


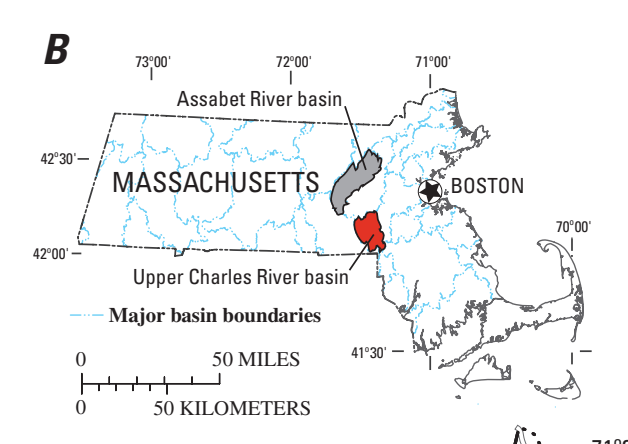

\section{EXPLANATION}

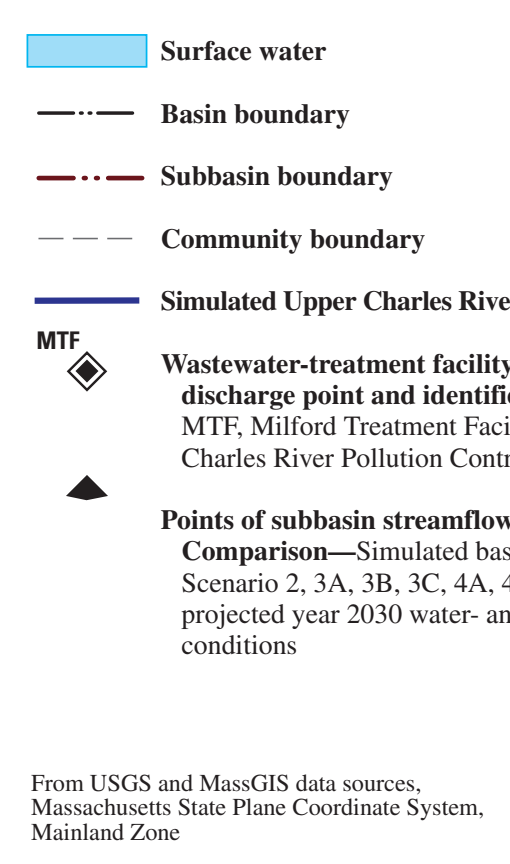

Figure 1. Location of subbasins and points of simulated streamflow comparison for (A) Assabet River Basin (1997-2001) and (B) Upper Charles River Basin (1989-98), eastern Massachusetts.-Continued 
three-dimensional, finite-difference ground-water-flow model code MODFLOW-2000 (Harbaugh and others, 2000). Steadystate and transient models were developed. For both study areas, the vertical discretization consisted of two layers of variable thickness, and the horizontal discretization consisted of a grid of uniformly spaced cells $200 \mathrm{ft}$ on a side. The grid of cells was composed of 700 rows and 290 columns for the Assabet River Basin model and 420 rows and 325 columns for the Upper Charles River Basin model. The regional character of the models makes them well-suited to represent the changes implemented at the relatively large scale of a subbasin or group of subbasins-for example, altering the recharge rate to reflect a change in regional land use. Regional-scale models are less well-suited to represent localized effects; for example, the effect of withdrawals from a specific well on a specific tributary would be better represented by a model with finer grid spacing and more than two layers.

Streams were modeled as head-dependent flow boundaries using the Stream Routing Package (Prudic, 1989) of MODFLOW-2000. This package simulates the hydraulic interaction between the aquifer and adjoining streams and tracks the amount of water in each modeled stream. Modeled streams were divided into reaches, corresponding to individual model cells, and segments, which are groups of reaches that are connected in downstream order (Prudic, 1989). The stream reaches in the Assabet River Basin model consisted of 10,460 model cells grouped into 692 stream segments, and the stream reaches in the Upper Charles River Basin model consisted of 3,012 model cells grouped into 77 stream segments. Water may flow either into or out of the modeled aquifer. Inflow, or leakage, is calculated by multiplying the specified streambed conductance by the difference between the stream stage and the water level (head) in the underlying aquifer. During the simulation, streams may go dry when stream leakage to the aquifer exceeds inflows from upstream reaches. Flows in streams are simulated as base flow, which is ground-water inflow plus any wastewater discharge to streams. The simulated streamflows are average nonstorm streamflows or base flows (DeSimone, 2004; DeSimone and others, 2002; Eggleston, 2004). The component of streamflow that resulted from direct or storm runoff was not included in the groundwater-flow model nor reported in this study.

The computer models developed for each study repeated average monthly water-withdrawal and discharge rates and average annual recharge values determined for a specific period of years for each year in the simulation period; this type of approach is known as a dynamic equilibrium approach. Transient computer models were used to simulate dynamic equilibrium or the condition in which there is no net change in ground-water storage from year to year (Barlow and Dickerman, 2001). The Assabet River and Upper Charles River Basin models each used a simulation period of 5 years, so that after five annual cycles, the effects of the initial conditions were eliminated. The periods for which average monthly and average annual rates were determined for use in the models were 1997 through 2001 for the Assabet River Basin study and 1989 through 1998 for the Upper Charles River Basin study.

Precipitation recharge rates in the Assabet River Basin model varied by surficial geology — sand and gravel stratified glacial deposits and till and bedrock uplands. Precalibration recharge rates were estimated by DeSimone (2004) by using (1) streamflow records and (2) a water-balance approach. Calibrated model recharge rates were $28.2 \mathrm{in} / \mathrm{yr}$ for sand and gravel stratified glacial deposits and $22.5 \mathrm{in} / \mathrm{yr}$ for till and bedrock uplands (DeSimone, 2004). The Recharge package of MODFLOW-2000 was used to apply all recharge fluxes as specified fluxes to the upper model layer in the active model area. No recharge was simulated for June through September; September is the representative dry month used in the basecase Assabet River Basin model (DeSimone, 2004).

Precipitation recharge rates in the Upper Charles River Basin used by Eggleston (2004) were slightly modified from those used by DeSimone and others (2002) and were assigned on the basis of land use and surficial geology. DeSimone and others (2002) defined 20 recharge categories for the study area. The rates were assigned on the basis of seven types of land use (forest, open space, wetland, open water, low-density residential, high-density residential, and commercial), two types of surficial geology (sand and gravel glacial deposits, and till or bedrock), and whether or not septic-system return flow was present. The recharge categories and associated rates used by DeSimone and others (2002) were based, in turn, on those used by Zarriello and Ries (2000) in a watershed model of the Ipswich River Basin in northeastern Massachusetts. DeSimone and others (2002) increased recharge rates in the computer model of the Upper Charles River Basin during the model calibration process. The calibrated model recharge rate used in undeveloped areas of sand and gravel was $24.1 \mathrm{in} / \mathrm{yr}$, and the area-weighted average rate for the entire model area was $22.5 \mathrm{in} / \mathrm{yr}$ (DeSimone and others, 2002).

\section{Environmental Setting}

The Assabet and Upper Charles River Basins are about 30-40 mi west and southwest of Boston, Mass. (fig. 1). The area of the Assabet River Basin is $177 \mathrm{mi}^{2}$ and includes all or part of 20 communities. The area of the Upper Charles River Basin is $102 \mathrm{mi}^{2}$ and includes all or part of 13 communities. Topography in the basins ranges from gently rolling to hilly, with steep slopes in the western parts of the basins. Elevations range from 100 to $750 \mathrm{ft}$ above NAVD 88 in the Assabet River Basin and 120 to $550 \mathrm{ft}$ above NAVD 88 in the Upper Charles River Basin. Land use in both basins was forest or open (about 50 percent), residential (27-28 percent, mostly low and medium density), agriculture (5-8 percent), commercial and industrial (3.5-5 percent) and water and wetlands (about 5-8 percent) (MassGIS, 1997, 2001). 


\section{Hydrogeology}

The hydrogeologic settings within the Assabet and Upper Charles River Basins, which are about 6 mi apart at the closest point, are similar. Three major geologic units are in both basins. Unconsolidated and discontinuous glacial deposits of sand and gravel typically are found in areas of lower elevation, where rivers and major tributaries are located. Glacial till, composed of an unsorted, unstratified mixture of clay, silt, sand, gravel, cobbles, and boulders, can form relatively thick deposits in upland areas. In the study area, crystalline bedrock underlies the glacial deposits and till. Ground water has been observed in all three geologic units; the sand and gravel glacial deposits (covering about 43 percent of the Assabet River Basin and about 50 percent of the Upper Charles River Basin study areas) were the most productive aquifers.

Precipitation, which averaged about 47 in/yr from 1957 through 2000 in the study area, is the primary source of recharge for the ground-water system. Precipitation recharge is the fraction of precipitation that infiltrates through the land surface and reaches the water table. Precipitation recharge rates vary over time and by location due to varying climatic conditions, types of vegetation, soil saturation, and landsurface slope and permeability - all of which determine the relative ease with which water can infiltrate into a soil or rock type.

\section{Water Use}

Ground water is the source of stream base flow and most water supply in the Assabet and Upper Charles River Basins. Most production wells are screened in the glacial aquifers along the tributary streams and main river channels. Water use in the basin consists primarily of water withdrawals for public supply, domestic use, and agriculture. Most water withdrawn for these purposes is returned to ground or surface water as wastewater. Much of the wastewater from publicly supplied water is transferred to downstream treatment facilities along the Assabet and Charles Rivers. The treated wastewater then is discharged to the rivers. If the amount of base flow in the river from ground water is diminished due to depletion by ground-water withdrawals, wastewater can become a greater percentage of river flow and thereby affect downstream water quality. In some tributaries, decreased streamflow may result in the loss of habitat for fish and other aquatic species.

Water imported for public supply from sources outside of the basin represents an inflow when it is discharged after use to ground or surface water in the basin. Water that is used consumptively - the component of a withdrawal that is removed permanently from the basin through evaporation or other processes-is a net outflow from the ground-water system in areas of private water supply and waste disposal. In areas of public supply, water used consumptively is incorporated into the difference between water withdrawals and wastewater-return flows. Water use in the Assabet River Basin results in a net import of water, which eventually becomes wastewater, and a net transfer of water from ground-water to surface-water systems (DeSimone, 2004; DeSimone and others, 2002; Eggleston, 2004).

Municipal water-supply systems (wells and surfacewater reservoirs) supplied most water users in 12 of the 20 communities and served about 80 percent of the population in the Assabet River Basin in 2000. Several communities that are only partly within the basin received water from sources in the adjacent Blackstone, Concord, Nashua, or Sudbury River Basins as well as in the Assabet River Basin (DeSimone, 2004). The communities of Marlborough, Northborough, and Clinton in the study area received water from the Massachusetts Water Resources Authority (MWRA) from sources in west-central Massachusetts.

Treated wastewater was discharged to the Assabet River from municipal water-treatment facilities in Westborough, Marlborough, Hudson, and Maynard. These facilities treated wastewater from eight communities, which represented about 50 percent of the basin population. Wastewater discharged from the four municipal facilities included water withdrawn from sources in and outside the basin. For example, wastewater from Shrewsbury that originated from sources in the Blackstone River Basin was treated and discharged at the Westborough facility (DeSimone, 2004). More descriptive information about basin hydrogeology and water use can be found in DeSimone (2004).

Withdrawals in the Upper Charles River Basin, like those in the Assabet River Basin, were primarily for public supply. Water for public supply was withdrawn from 33 wells or wellfields in the stratified glacial aquifers and from two locations on the Charles River in Milford in 2001. In addition, several private ground- and surface-water withdrawals exceeded $0.1 \mathrm{Mgal} / \mathrm{d}$. These included withdrawals by three golf courses and a power plant (DeSimone and others, 2002). Wastewater from Milford was treated and discharged to the Charles River at the Milford Treatment Facility (MTF) in Hopedale; wastewater from Medway, Franklin, Millis, and Bellingham was treated and discharged at the Charles River Pollution Control District (CRPCD) facility in Medway. More information about the basin can be found in DeSimone and others (2002) and Eggleston (2004).

\section{Projected 2030 Land and Water Use}

Data that formed the basis for the water- and landuse scenarios simulated for this study were provided by the MAPC. The data sets provided by MAPC include (1) year 2030 water demand by community (Martin Pillsbury, Metropolitan Area Planning Council, written commun., 2006); (2) a Geographic Information System (GIS) coverage of developable land (Timothy Reardon, Metropolitan Area Planning Council, written commun., 2006); and (3) a GIS coverage of subareas within communities and associated 
projections of year 2030 new development (Timothy Reardon, Metropolitan Area Planning Council, written commun., 2006).

\section{Estimation Methods}

Water demands for each community were calculated by MAPC on the basis of a combination of (1) population and employment projections completed by MAPC, (2) the most recent residential- and employment-population data,

(3) baseline water-demand data for each community,

(4) the current permitted water-demand volumes for each community, and (5) assumed per capita use rates for residential and employment-related populations (Metropolitan Area Planning Council, written commun., 2005). The additional projected water demand for 2030 comprised three components: residential, commercial and industrial, and unaccounted-for water demand. The residential component was based on projected residential population increases and an average per capita water-use rate of 75 gallons per person per day, which is the current regional average (Metropolitan Area Planning Council, written commun., 2005). The commercial and industrial component was based on projected employment-population increases and per capita water-use rates for the employment categories of services (22.6 gal/d per employee), retail (92.6 gal/d per employee), and basic (15.0 gal/d per employee). Unaccounted-for demand was 15 percent of the residential and the commercial plus industrial demand (Metropolitan Area Planning Council, written commun., 2005).

The GIS coverage of vacant developable land included all the undeveloped, nonwetland areas within the study basins (figs. 2A and 2B) that potentially could be developed in the future (Metropolitan Area Planning Council, written commun., 2006). The coverage of the land areas included attributes derived from the land-use categories of the MassGIS Zoning Datalayer Description page (MassGIS, 2006).

The GIS coverage of year 2030 new development included the number of acres of residential and commercial land projected to be developed by year 2030. Each community within the Assabet River (fig. 3A) and Upper Charles River (fig. 3B) Basins was subdivided into a community-specific number of smaller subareas, each of which had area-specific data projected for year 2030. This area-specific data included new residential acres for 2030, new commercial acres for 2030, population for year 2000, and population for 2030 . The number of developable acres, the acres predicted to be developed by 2030, and the percentage of developable land predicted to be developed by 2030 are shown in table 1 for the Assabet and Upper Charles River Basins.

\section{Model Simulation of Hydrologic Conditions in Year 2030}

The comparisons made in this study were based on ground-water-model simulations of projected 2030 water- and land-use conditions. The scenarios developed for this study were defined in consultation with the project TAC.

\section{Model Scenarios}

Seven of eight scenarios include the effects of 2030 water use, 2030 land use, and the combination of 2030 water use and 2030 land use. One scenario is the basecase to which all 2030 scenario simulation results are compared. The scenarios are

1. basecase water use and land use for 1997 through 2001 in the Assabet River Basin and 1989 through 1998 in the Upper Charles River Basin;

2. year 2030 water use and basecase land use, which included projected year 2030 withdrawals for public supply, return flow in areas of public supply and private septic systems, consumptive use in areas of private supply and private septic systems, and wastewater-treatment facility discharges;

3. year 2030 land use and basecase water use with

A. year 2030 commercial development with a decrease in recharge of 50 percent;

B. year 2030 commercial (scenario 3A) and residential development, with a decrease in recharge of 10 percent projected for areas of residential development; and

C. year 2030 commercial (scenario 3A) and residential development, with an increase in recharge of 10 percent projected for areas of residential development;

4. year 2030 water and land use combined with

A. year 2030 water use and commercial development with a decrease in recharge of 50 percent;

B. year 2030 water use and commercial (scenario 4A) and residential development, with a decrease in recharge of 10 percent projected for areas of residential development; and

C. year 2030 water use and commercial (scenario 4A) and residential development, with an increase in recharge of 10 percent projected for areas of residential development.

In order to incorporate the 2030 water- and land-use projections of the MAPC into the USGS hydrologic models of the study areas, a series of procedures were followed. 
A
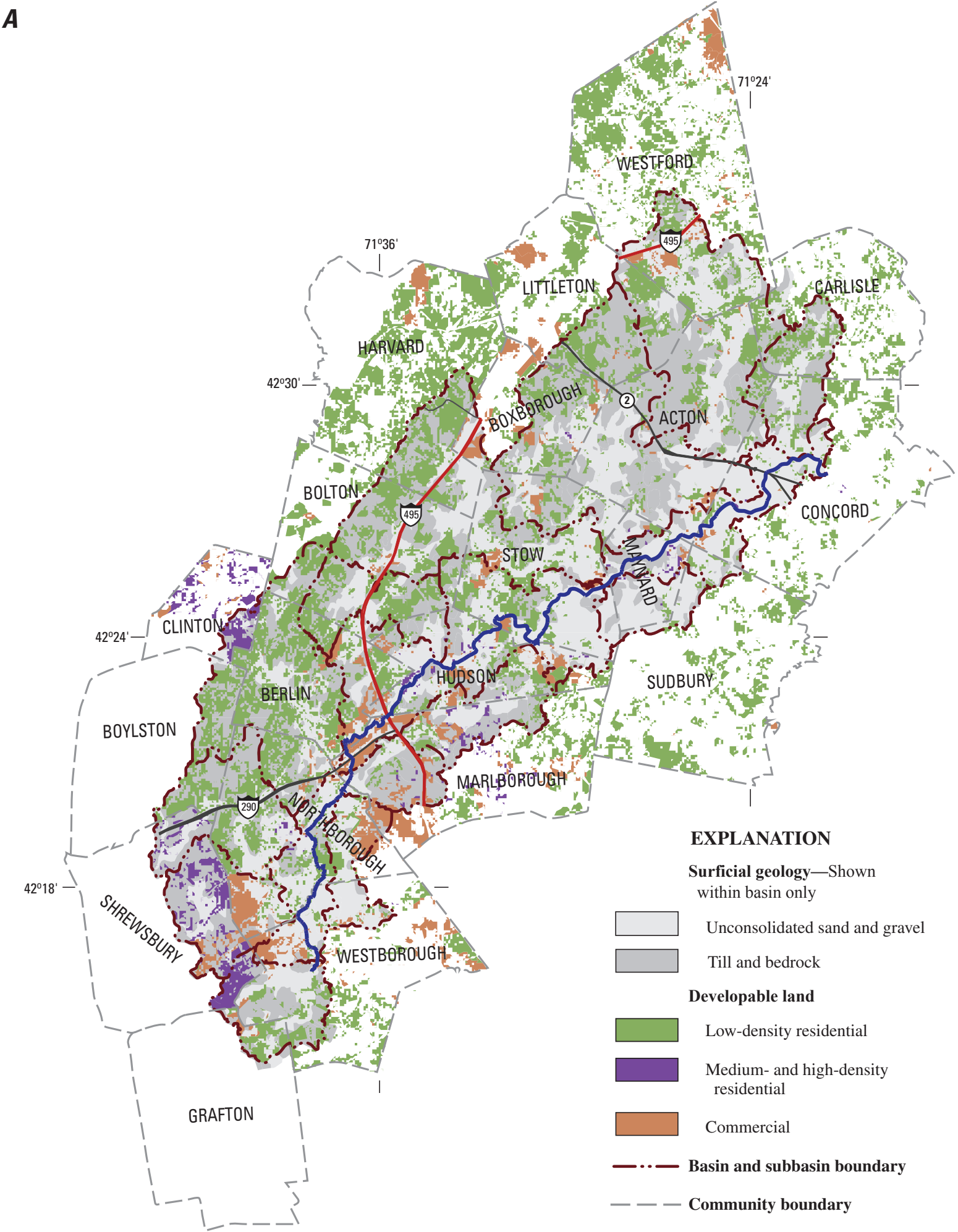

\section{EXPLANATION}

Surficial geology—Shown within basin only

Unconsolidated sand and gravel

Till and bedrock

Developable land

MassGIS data sources,

Massachusetts State Plane Coordinate System,

Mainland Zone

Low-density residential

Medium- and high-density residential

Commercial

— - - Basin and subbasin boundary

- - Community boundary

Simulated Assabet River



Figure 2. Developable land areas and surficial geology in (A) Assabet and (B) Upper Charles River Basins, eastern Massachusetts. Data provided by the Metropolitan Area Planning Council (written commun., 2006). Data were not available outside the study area for Boylston, Shrewsbury, and Grafton. 
B



-..- Basin and subbasin boundary

- - Community boundary

Simulated Upper Charles River

Figure 2. Developable land areas and surficial geology in (A) Assabet and (B) Upper Charles River Basins, eastern Massachusetts. Data provided by the Metropolitan Area Planning Council (written commun., 2006). Data were not available outside the study area for Boylston, Shrewsbury, and Grafton.-Continued 
A

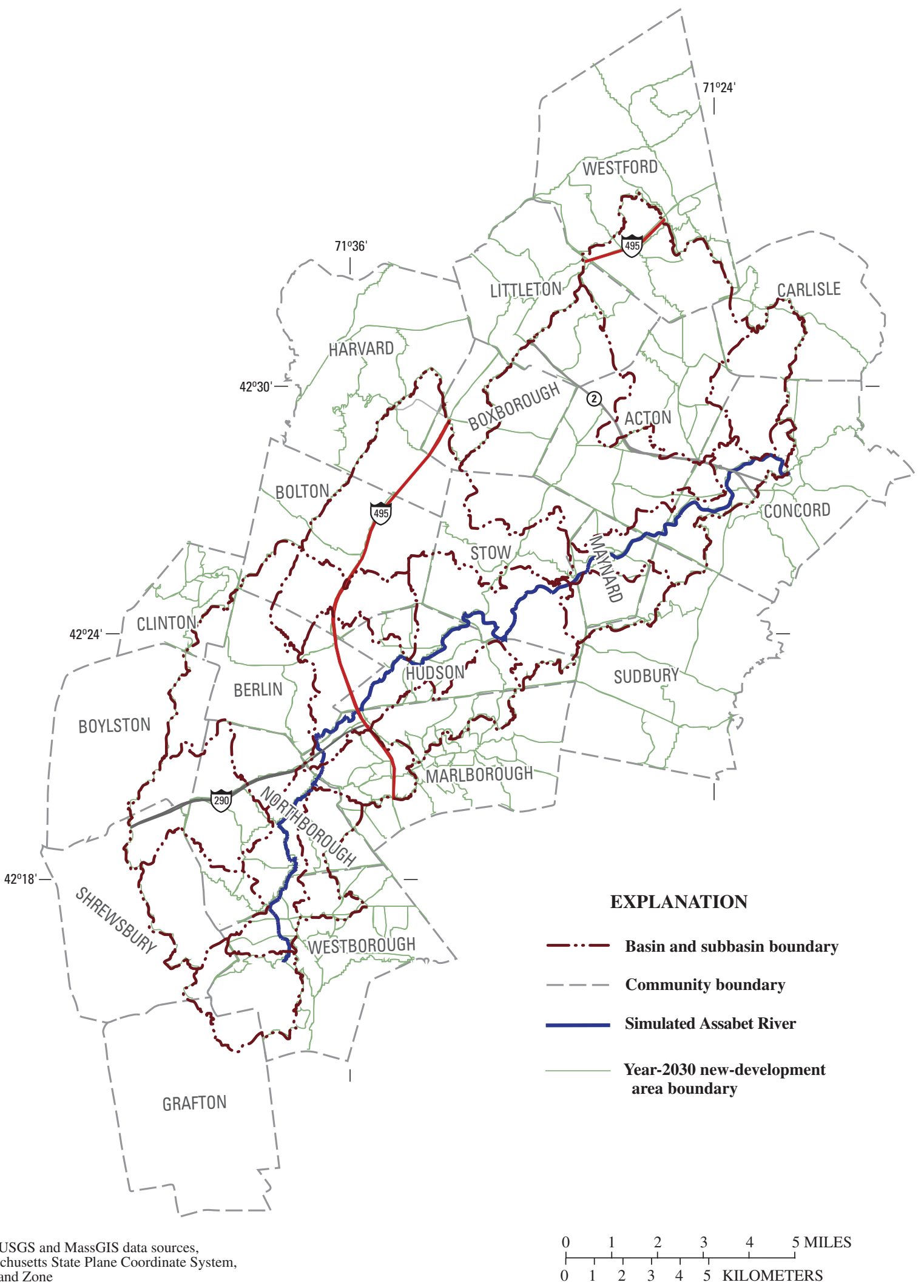

Massachusetts State Plane Coordinate System,

Mainland Zone

Figure 3. Locations of subbasin and year 2030 new-development areas in (A) Assabet River Basin and (B) Upper Charles River Basin, eastern Massachusetts. 
$\boldsymbol{B}$

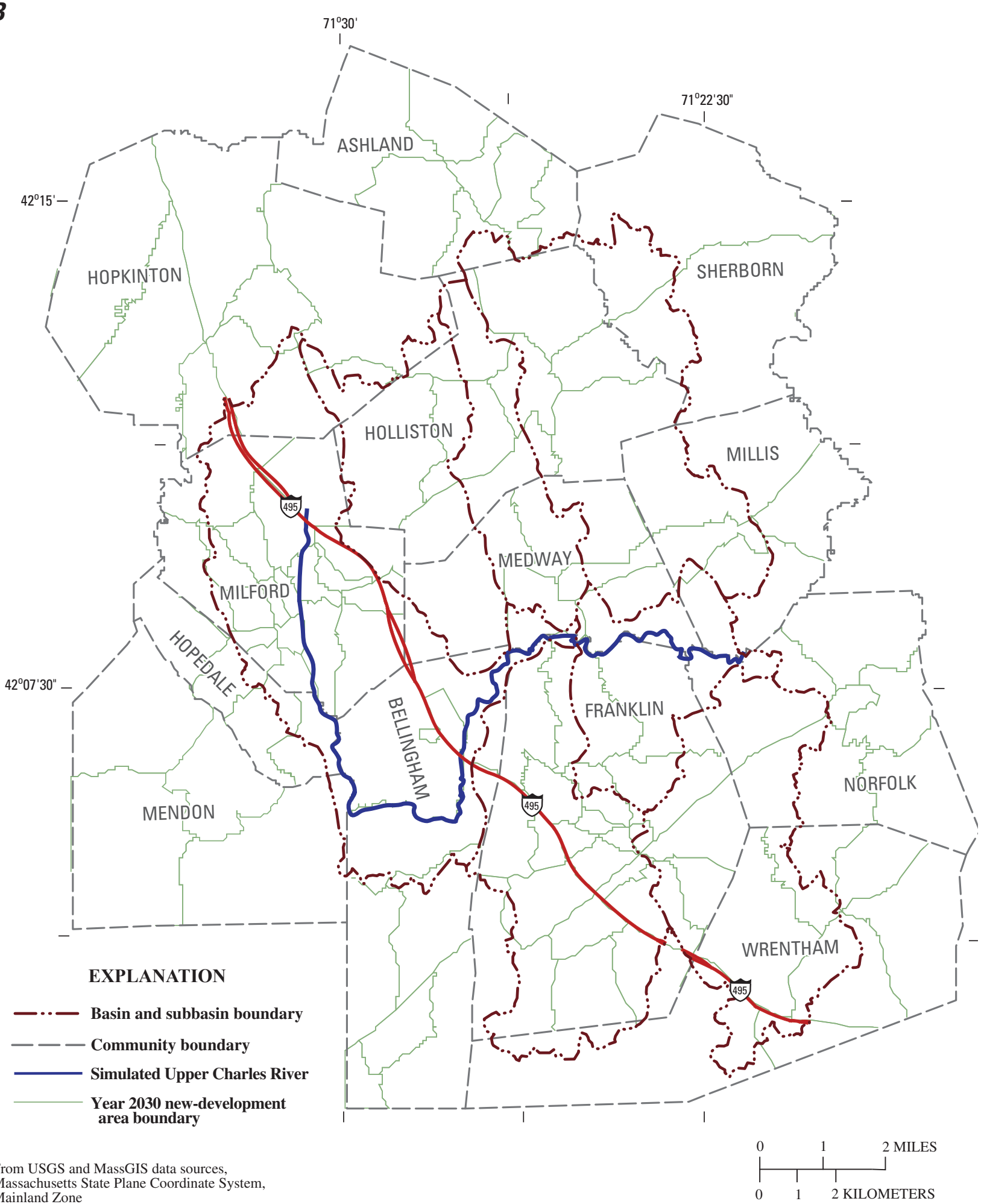

Massachusetts State Plane Coordinate System,

Figure 3. Locations of subbasin and year 2030 new-development areas in (A) Assabet River Basin and (B) Upper Charles River Basin, eastern Massachusetts. - Continued 


\section{Simulated Effects of Water-Use and Land-Use Changes on Streamflow, Assabet and Upper Charles River Basins}

Table 1. Area available for development and area predicted to be developed by 2030 in subbasins of the Assabet and Upper Charles River Basins, eastern Massachusetts.

[Difference in residential acres in Taylor subbasin may be due to exclusion of wetlands from area available for future development.]

\begin{tabular}{|c|c|c|c|c|c|c|}
\hline \multirow{3}{*}{ Subbasin } & \multicolumn{2}{|c|}{$\begin{array}{l}\text { Area available for future development } \\
\text { (acres) }\end{array}$} & \multicolumn{4}{|c|}{ Area predicted to be developed by 2030} \\
\hline & \multirow{2}{*}{ Residential } & \multirow{2}{*}{ Commercial } & \multicolumn{2}{|c|}{$\begin{array}{c}\text { Area } \\
\text { (acres) }\end{array}$} & \multicolumn{2}{|c|}{$\begin{array}{l}\text { Area, as a percentage of } \\
\text { available area }\end{array}$} \\
\hline & & & Residential & Commercial & Residential & Commercial \\
\hline \multicolumn{7}{|c|}{ Assabet River Basin } \\
\hline Assabet Main Stem Headwaters & 1,349 & 156 & 1,027 & 41 & 76 & 26 \\
\hline Assabet Main Stem Upper & 471 & 173 & 408 & 121 & 87 & 70 \\
\hline Assabet Main Stem Middle & 2,417 & 1,170 & 900 & 310 & 37 & 26 \\
\hline Assabet Main Stem Lower & 737 & 523 & 533 & 186 & 72 & 36 \\
\hline Cold Harbor and Howard Brooks & 1,905 & 10 & 682 & 0 & 36 & 4 \\
\hline Danforth Brook & 1,641 & 37 & 392 & 5 & 24 & 13 \\
\hline Elizabeth Brook & 3,836 & 348 & 1,087 & 67 & 28 & 19 \\
\hline Fort Meadow Brook & 703 & 289 & 668 & 96 & 95 & 33 \\
\hline Fort Pond Brook & 2,823 & 349 & 1,164 & 113 & 41 & 32 \\
\hline Hop Brook & 812 & 920 & 612 & 203 & 75 & 22 \\
\hline Nashoba Brook & 3,175 & 349 & 1,568 & 111 & 49 & 32 \\
\hline North Brook & 4,977 & 181 & 908 & 32 & 18 & 18 \\
\hline Spencer Brook & 1,157 & 0 & 333 & 0 & 29 & 0 \\
\hline Stirrup Brook & 263 & 511 & 173 & 121 & 66 & 24 \\
\hline Taylor Brook ${ }^{1}$ & 114 & 7 & 125 & 3 & 110 & 34 \\
\hline \multicolumn{7}{|c|}{ Upper Charles River Basin } \\
\hline Main Stem West Upper Charles & 3,407 & 1,411 & 1,400 & 370 & 41 & 26 \\
\hline Main Stem East Upper Charles & 1,244 & 44 & 889 & 10 & 72 & 23 \\
\hline Bogastow Brook & 3,312 & 276 & 1,458 & 81 & 44 & 29 \\
\hline Chicken Brook & 1,292 & 292 & 728 & 19 & 56 & 6 \\
\hline Hopping Brook & 2,199 & 325 & 1,068 & 113 & 49 & 35 \\
\hline Mill River & 3,241 & 354 & 1,649 & 61 & 51 & 17 \\
\hline Mine Brook & 1,658 & 616 & 1,197 & 181 & 72 & 29 \\
\hline
\end{tabular}


These procedures were necessary to disaggregate annual water-use projections for 2030 to the monthly time step of the models and to distribute the projected changes in ground-water recharge across the model areas. These procedures are fully described in appendix 1.

\section{Evaluation of 2030 Model Simulation Results}

The USGS ground-water-flow models of the Assabet and Upper Charles River Basins were modified as described in appendix 1 and used to simulate changes in hydrologic conditions in the study areas due to projected changes in water and land use. This section describes the results of the seven 2030 scenarios of water- and land-use changes in comparison to basecase conditions. Basecase streamflows by subbasin are shown in figures 4 through 11 for cumulative downstream streamflow and for streamflow from individual subbasins in both river basins. Monthly water-supply rates and waterbudget changes from the basecase for average annual, March, and September conditions for both river basins are shown in appendixes 2 through 6 .

Ground-water-flow models, in general, simulate streamflows and water levels in surface-water features only to the extent that they represent discharge areas or boundaries of the ground-water system. Flows in simulated streams represent the nonstorm component of flow that originated as groundwater discharge (base flow), plus any augmentations resulting from wastewater discharge (DeSimone and others, 2002). For simplicity in this report, the term "streamflow" is used to represent flows in modeled streams calculated by the ground-water-flow model. Because of the overall size of the modeled areas, the average volumes of water moving through the ground-water systems, and the major goal of comparing differences in streamflow on a subbasin scale among individual scenarios simulated by existing calibrated groundwater models, streamflows and changes in streamflow of less than $0.1 \mathrm{ft}^{3} / \mathrm{s}$ were considered to be insignificant.

\section{Assabet River Basin}

Changes in streamflow from the basecase (1997 through 2001) resulted from combinations of projected year 2030 water and land use in the Assabet River Basin. Overall average annual streamflow changes were comparatively small-the average decrease in streamflows was $0.18 \mathrm{ft}^{3} / \mathrm{s}$, and the average increase in streamflows was $0.14 \mathrm{ft}^{3} / \mathrm{s}$ for all scenarios and subbasins (fig. 5). The overall average annual basecase
(1997-2001) streamflows were $107.5 \mathrm{ft}^{3} / \mathrm{s}$ for cumulative downstream flow (fig. 4) and $14.5 \mathrm{ft}^{3} / \mathrm{s}$ for streamflow from individual subbasins (fig. 5). Year 2030 water use (scenario 2) caused an increase in cumulative downstream flows in the main-stem subbasins (fig. 4), but as total streamflow volume increased downstream, the percent change in total streamflow decreased. These cumulative main-stem streamflow increases were due mainly to wastewater-effluent discharge to the Assabet River from treatment facilities in Westborough, Marlborough, Hudson, and Maynard.

\section{Wastewater Flows}

Treated-wastewater discharges to the surface-water flow system accounted for larger percentages of the total streamflow in the main stem Assabet subbasins in September than annually or in March. Treated wastewater discharges to streams from all wastewater-treatment facilities (WWTF) increased for each month except in the Main-Stem Lower subbasin, which had a calculated decrease from basecase in February, April, and November. Increased treated-effluent discharges can affect water quality as WWTF discharge becomes a greater proportion of the streamflows downstream from the facilities. WWTF discharge was a greater proportion of Assabet main-stem streamflow in the Upper subbasin than it is in the Lower subbasin - that is, the percentage of WWTF discharge in streamflow decreased with distance downstream. This may be due, in part, to the distribution of wastewater discharges along the main stem Assabet River-the largest of four discharge volumes entered the river near the headwaters. The proportion of streamflow that was WWTF discharge was reduced by ground-water inflow and tributary inflows to the main stem from other subbasins. In March, when overall streamflows were relatively high, projected 2030 wastewater volumes for all scenarios averaged 16,9, and 5 percent of model-calculated streamflow out of the Assabet Main Stem Upper, Middle, and Lower subbasins, ${ }^{1}$ respectively (fig. 12A). This is essentially the same as the basecase result. In September, wastewater averaged for all scenarios 60, 36, and 22 percent of model-calculated streamflow out of the three main-stem subbasins, respectively (fig. 12A). These wastewater volumes are about 10 percent higher than those for the basecase. Changes in wastewater discharge (in cubic feet per second) from the basecase for the main stem Assabet River are listed in table 2.

\footnotetext{
${ }^{1}$ These subbasins were arbitrarily defined as fractions of the main-stem length.
} 


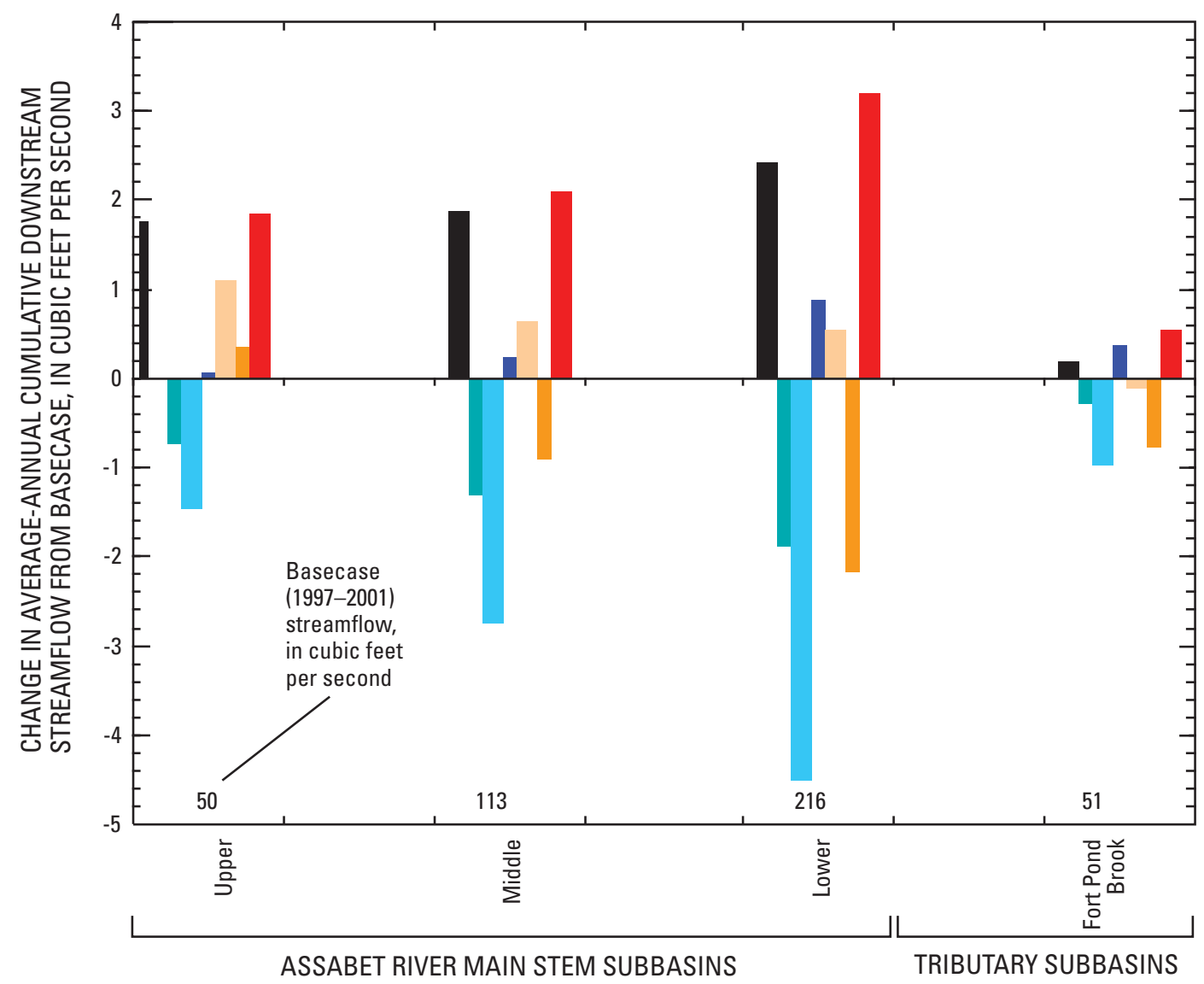

Scenario

\section{EXPLANATION}

2: Basecase land use, 2030 water use

3A: Basecase water use, 2030 land use, and decreased commercial-area recharge by 50 percent

3B: Basecase water use, 2030 land use, decreased commercial-area recharge by 50 percent, and decreased residential-area recharge by 10 percent

- 3C: Basecase water use, 2030 land use, decreased commercial-area recharge by 50 percent, and increased residential-area recharge by 10 percent

4A: 2030 land use, 2030 water use, and decreased commercial-area recharge by 50 percent

4B: 2030 land use, 2030 water use, decreased commercial-area recharge by 50 percent, and decreased residential-area recharge by 10 percent

- 4C: 2030 land use, 2030 water use, decreased commercial-area recharge by 50 percent, and increased residential-area recharge by 10 percent

Figure 4. Change in simulated average-annual cumulative downstream streamflow from simulated basecase conditions for seven scenarios for Assabet River Main Stem subbasins, eastern Massachusetts. 


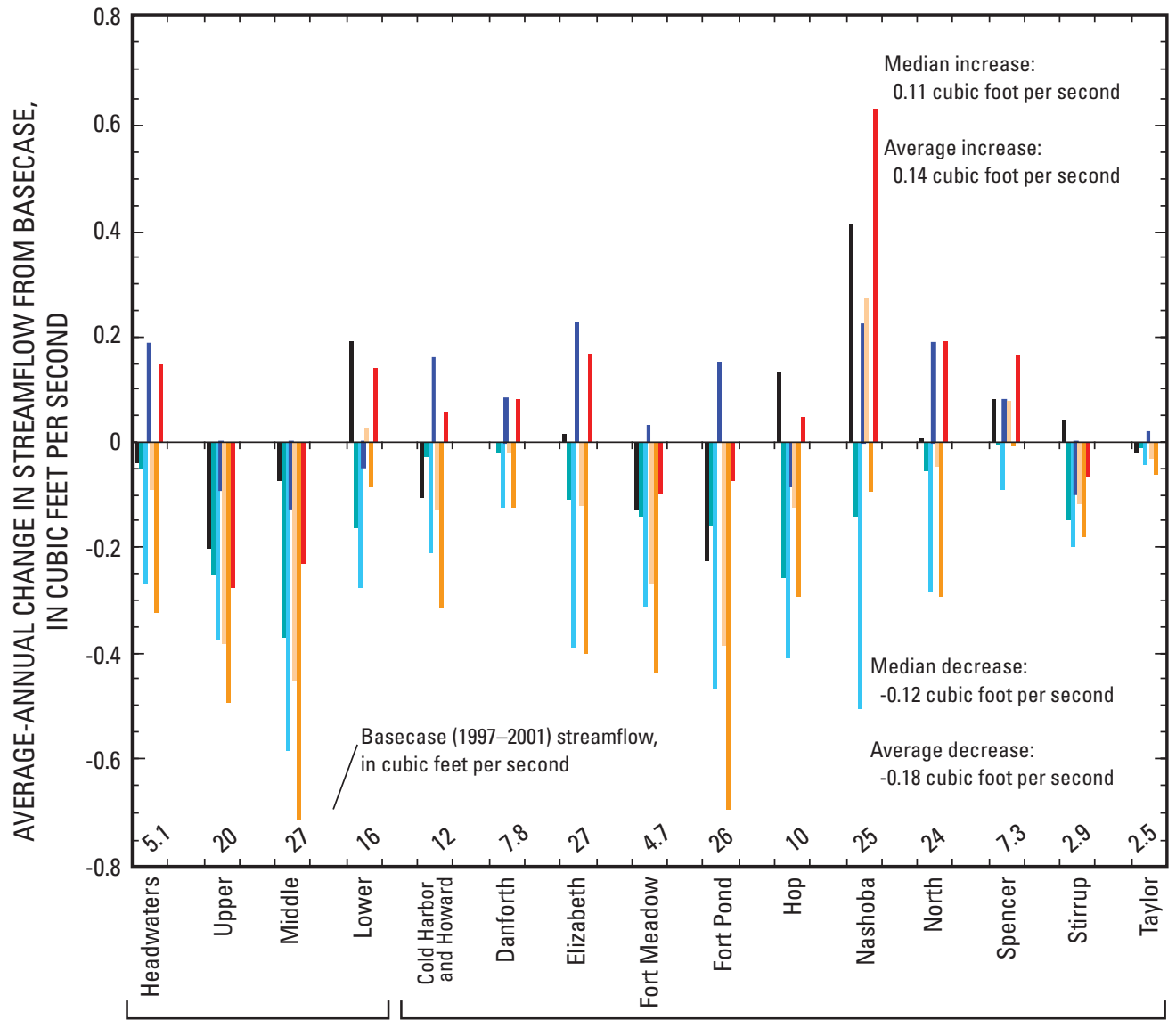

ASSABET MAIN STEM SUBBASINS

Scenario

TRIBUTARY SUBBASINS

\section{EXPLANATION}

2: Basecase land use, 2030 water use

3A: Basecase water use, 2030 land use, and decreased commercial-area recharge by 50 percent

3B: Basecase water use, 2030 land use, decreased commercial-area recharge by 50 percent, and decreased residential-area recharge by 10 percent

- 3C: Basecase water use, 2030 land use, decreased commercial-area recharge by 50 percent, and increased residential-area recharge by 10 percent

4A: 2030 land use, 2030 water use, and decreased commercial-area recharge by 50 percent

4B: 2030 land use, 2030 water use, decreased commercial-area recharge by 50 percent, and decreased residential-area recharge by 10 percent

- 4C: 2030 land use, 2030 water use, decreased commercial-area recharge by 50 percent, and increased residential-area recharge by 10 percent

Figure 5. Change in simulated average-annual streamflow from simulated basecase conditions for seven scenarios for individual subbasins in the Assabet River Basin, eastern Massachusetts. 

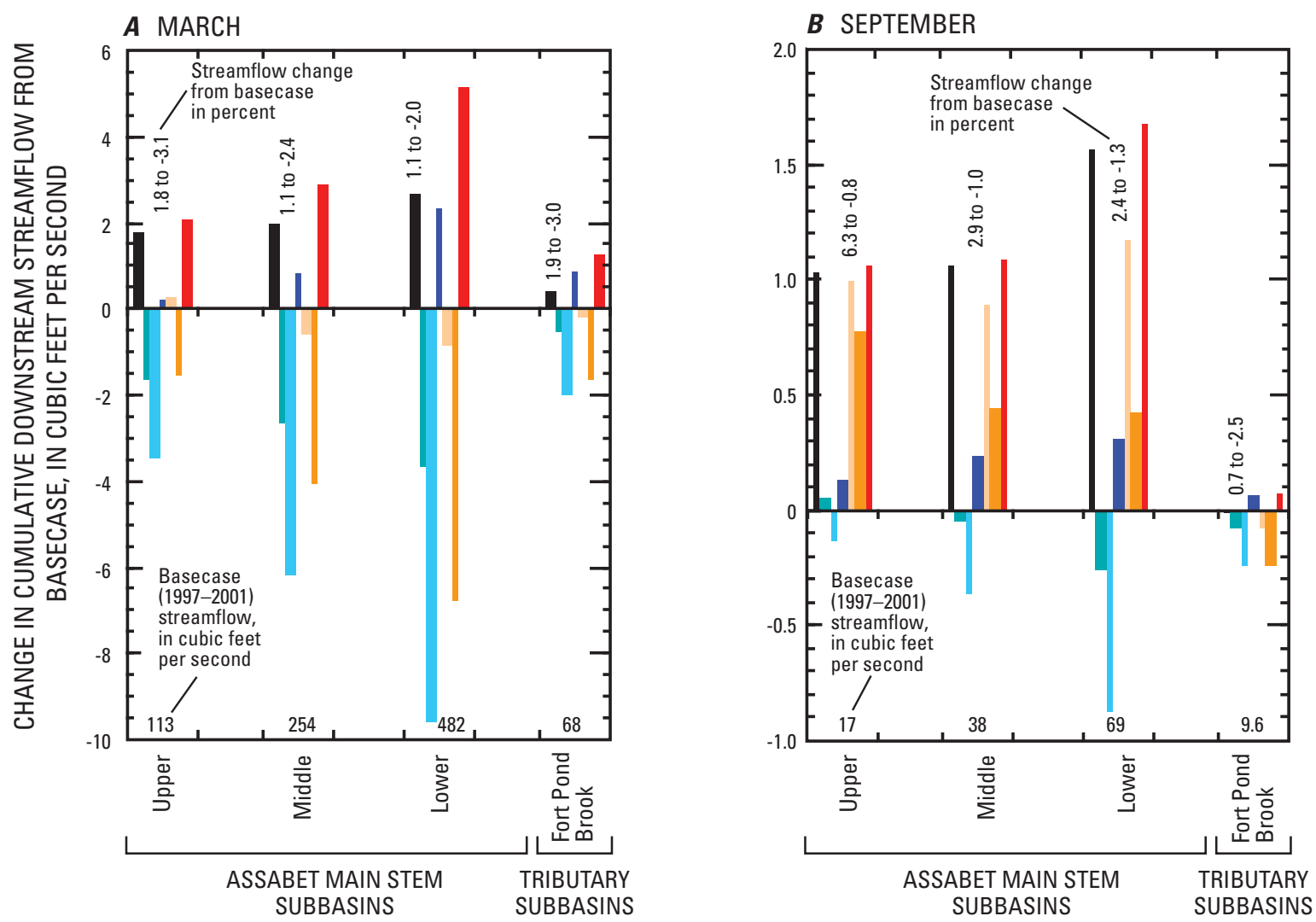

\section{Scenario}

\section{EXPLANATION}

- 2: Basecase land use, 2030 water use

3A: Basecase water use, 2030 land use, and decreased commercial-area recharge by 50 percent

- 3B: Basecase water use, 2030 land use, decreased commercial-area recharge by 50 percent, and decreased residential-area recharge by 10 percent

- 3C: Basecase water use, 2030 land use, decreased commercial-area recharge by 50 percent, and increased residential-area recharge by 10 percent

4A: 2030 land use, 2030 water use, and decreased commercial-area recharge by 50 percent

4B: 2030 land use, 2030 water use, decreased commercial-area recharge by 50 percent, and decreased residential-area recharge by 10 percent

- 4C: 2030 land use, 2030 water use, decreased commercial-area recharge by 50 percent, and increased residential-area recharge by 10 percent

Figure 6. Change in simulated cumulative downstream streamflow from simulated basecase conditions for seven scenarios in (A) March and (B) September for Assabet River Main Stem subbasins, eastern Massachusetts. 


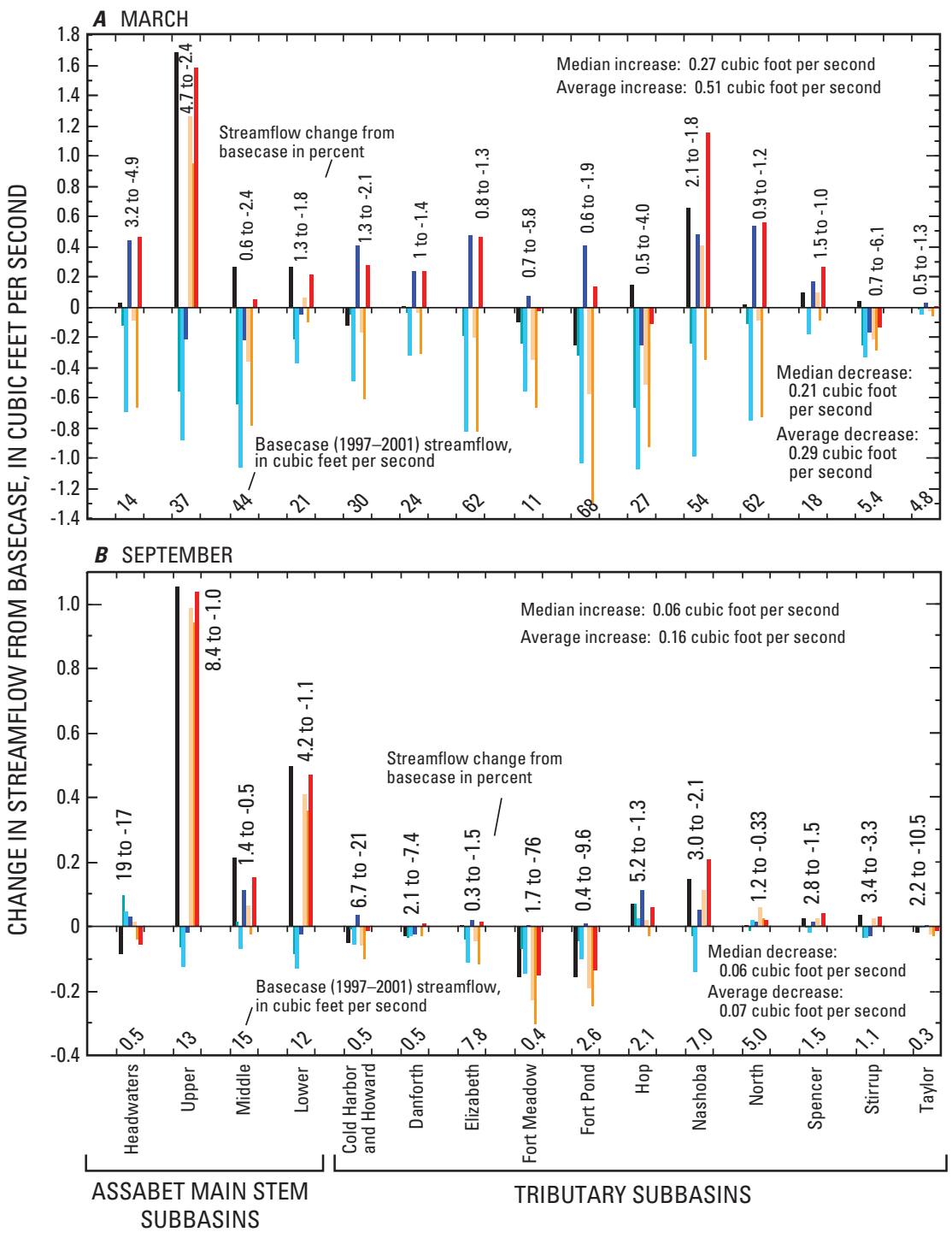

Figure 7. Change in simulated streamflow from simulated basecase conditions for seven scenarios in $(A)$ March and $(B)$ September for individual subbasins in the Assabet River Basin, eastern Massachusetts.



Figure 8. Change in simulated average-annual cumulative downstream streamflow from simulated basecase conditions for seven scenarios for Upper Charles River Main Stem subbasins, eastern Massachusetts.

\section{Scenario \\ EXPLANATION}

2: Basecase land use, 2030 water use

- 3A: Basecase water use, 2030 land use, and decreased commercial-area recharge by 50 percent

- 3B: Basecase water use, 2030 land use, decreased commercial-area recharge by 50 percent, and decreased residential-area recharge by 10 percent

- 3C: Basecase water use, 2030 land use, decreased commercial-area recharge by 50 percent, and increased residential-area recharge by 10 percent

4A: 2030 land use, 2030 water use, and decreased commercial-area recharge by 50 percent

4B: 2030 land use, 2030 water use, decreased commercial-area recharge by 50 percent, and decreased residential-area recharge by 10 percent

4C: 2030 land use, 2030 water use, decreased commercial-area recharge by 50 percent, and increased residential-area recharge by 10 percent 




Figure 9. Change in simulated average-annual streamflow from simulated basecase conditions for seven scenarios for individual subbasins in the Upper Charles River Basin, eastern Massachusetts.

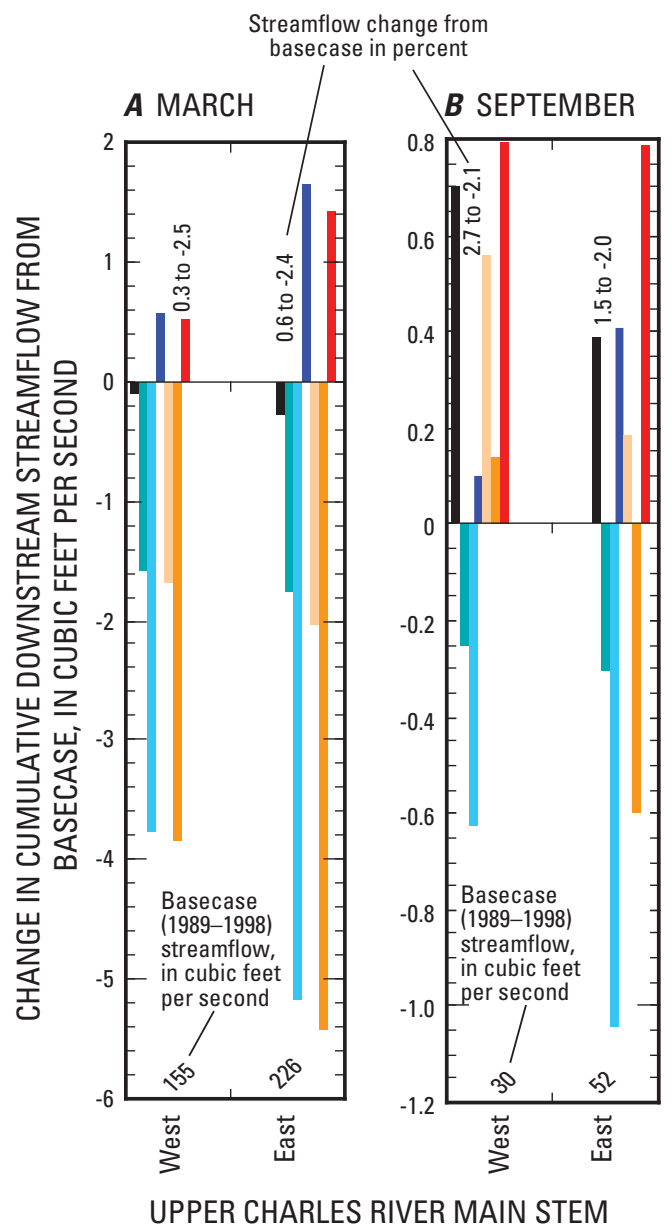

Figure 10. Change in simulated cumulative downstream streamflow from simulated basecase conditions for seven scenarios in (A) March and (B) September for Upper Charles River Main Stem subbasins, eastern Massachusetts.

\section{EXPLANATION}

Scenario

(For figures 9 and 10)

2: Basecase land use, 2030 water use

3A: Basecase water use, 2030 land use, and decreased commercial-area recharge by 50 percent

- 3B: Basecase water use, 2030 land use, decreased commercial-area recharge by 50 percent, and decreased residential-area recharge by 10 percent

- 3C: Basecase water use, 2030 land use, decreased commercial-area recharge by 50 percent, and increased residential-area recharge by 10 percent

4A: 2030 land use, 2030 water use, and decreased commercial-area recharge by 50 percent

4B: 2030 land use, 2030 water use, decreased commercial-area recharge by 50 percent, and decreased residential-area recharge by 10 percent

- 4C: 2030 land use, 2030 water use, decreased commercial-area recharge by 50 percent, and increased residential-area recharge by 10 percent 


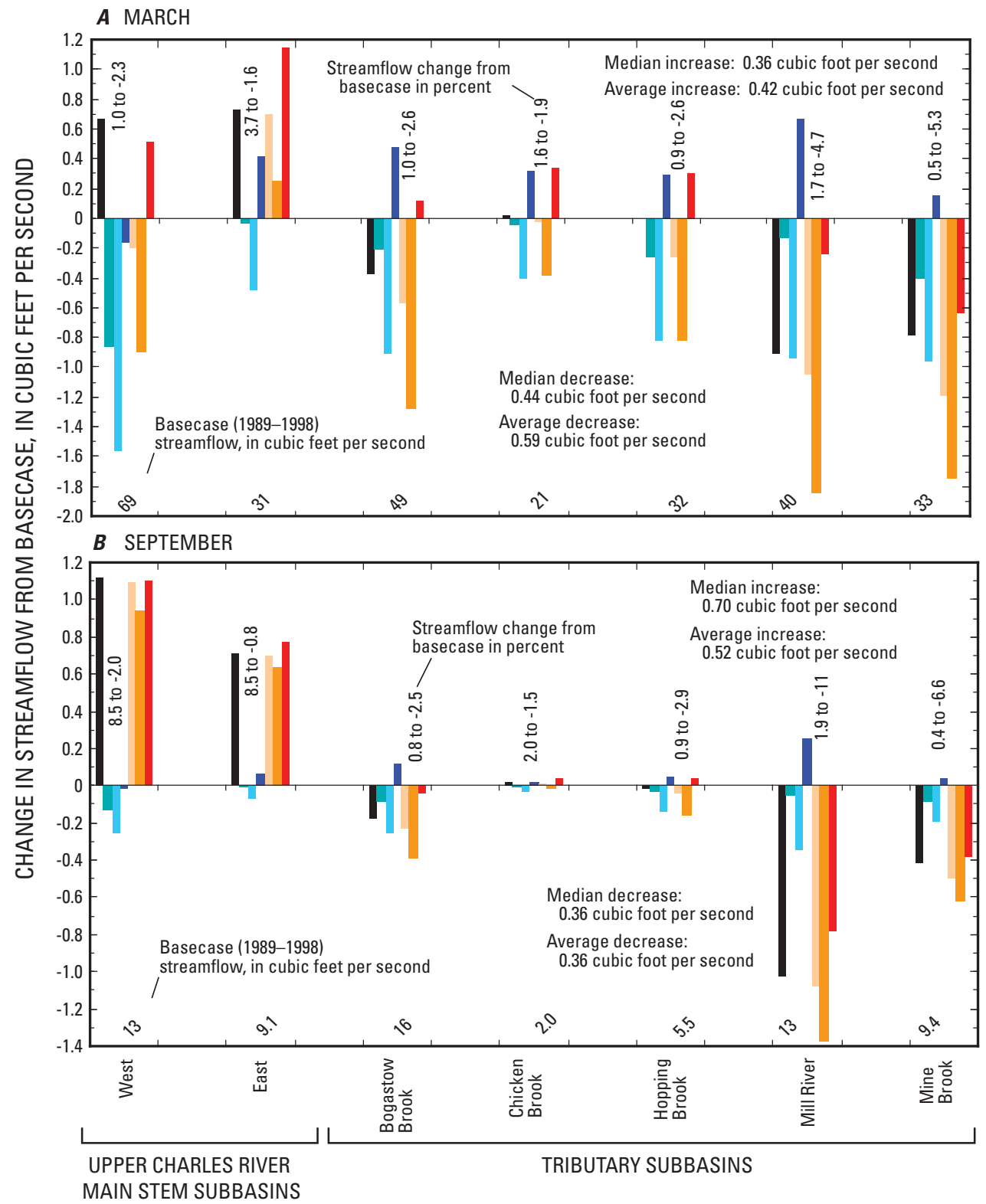

Scenario

\section{EXPLANATION}

2: Basecase land use, 2030 water use

3A: Basecase water use, 2030 land use, and decreased commercial-area recharge by 50 percent

- 3B: Basecase water use, 2030 land use, decreased commercial-area recharge by 50 percent, and decreased residential-area recharge by 10 percent

- 3C: Basecase water use, 2030 land use, decreased commercial-area recharge by 50 percent, and increased residential-area recharge by 10 percent

4A: 2030 land use, 2030 water use, and decreased commercial-area recharge by 50 percent

4B: 2030 land use, 2030 water use, decreased commercial-area recharge by 50 percent, and decreased residential-area recharge by 10 percent

4C: 2030 land use, 2030 water use, decreased commercial-area recharge by 50 percent, and increased residential-area recharge by 10 percent

Figure 11. Change in simulated streamflow from simulated basecase conditions for seven scenarios in ( $A$ ) March and (B) September for individual subbasins in the Upper Charles River Basin, eastern Massachusetts. 


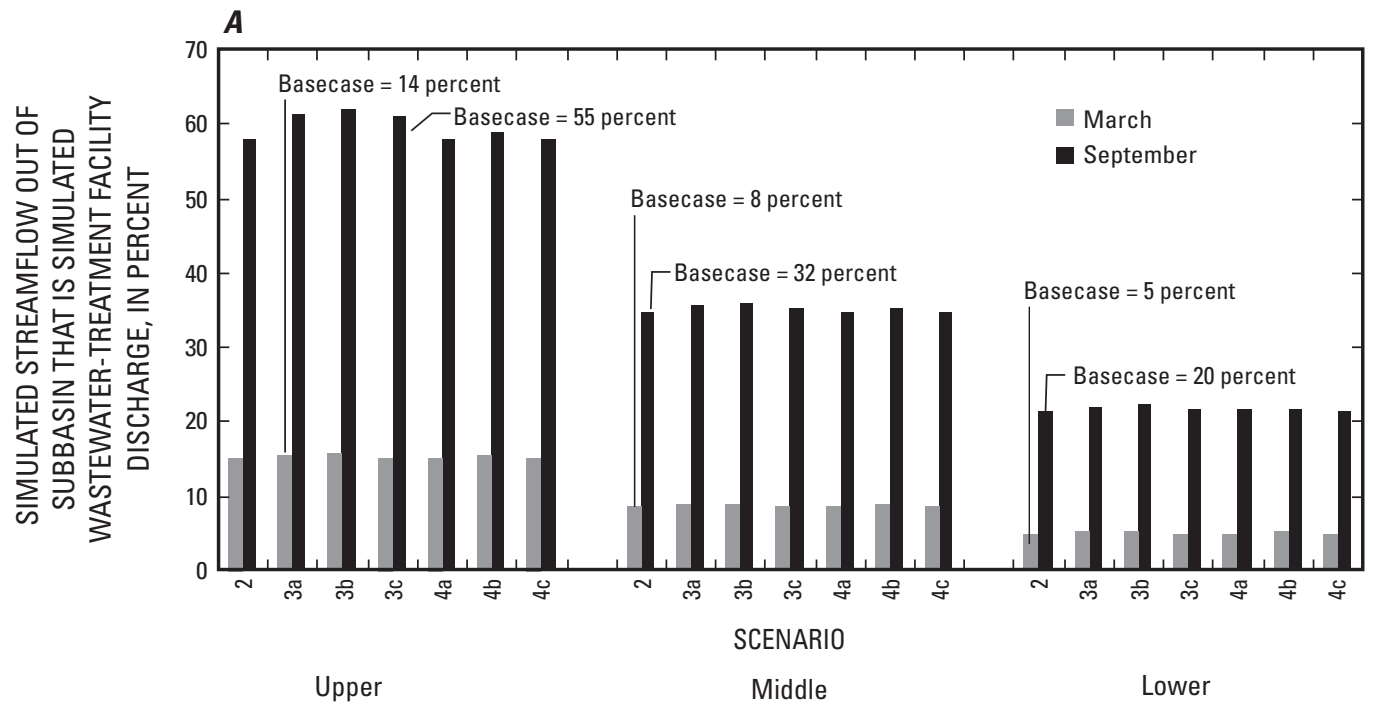

ASSABET MAIN STEM SUBBASINS



UPPER CHARLES RIVER MAIN STEM SUBBASINS

Figure 12. Percentage of simulated streamflow out of (A) Assabet and (B) Upper Charles River Main Stem subbasins that is simulated wastewater-treatment facility (WWTF) discharge for basecase and seven scenarios, eastern Massachusetts. 
Table 2. Changes in simulated monthly average wastewater discharge for each year 2030 scenario of water-use change from basecase conditions, Assabet River Basin, eastern Massachusetts.

[Values are in cubic feet per second, $\mathrm{ft}^{3} / \mathrm{s}$.]

\begin{tabular}{|c|c|c|c|c|c|c|c|c|c|c|c|c|c|}
\hline \multirow[t]{2}{*}{ Subbasin } & \multicolumn{13}{|c|}{$\begin{array}{l}\text { Change in simulated wastewater discharge } \\
\qquad\left(\mathrm{ft}^{3} / \mathrm{s}\right)\end{array}$} \\
\hline & Jan. & Feb. & Mar. & Apr. & May & June & July & Aug. & Sept. & Oct. & Nov. & Dec. & Average \\
\hline Assabet Main Stem Middle & .30 & .31 & .29 & .30 & .24 & .49 & .44 & .33 & .27 & .23 & .24 & .21 & .30 \\
\hline Assabet Main Stem Lower & .06 & -.02 & .06 & -.21 & .08 & .07 & .14 & .27 & .23 & .34 & -.18 & .11 & .08 \\
\hline
\end{tabular}

\section{Streamflow Changes by Subbasin}

The following discussion highlights the greatest simulated changes in cumulative downstream flow that occurred in the Assabet River. Changes in cumulative downstream flow in the main-stem subbasins were similar for all seven scenarios (fig. 6). Change in simulated streamflow and the change as a percentage of basecase streamflow for each subbasin and scenario are shown in table 3. Scenario 3B with decreased ground-water recharge from commercial and residential land-use change resulted mostly in decreases in cumulative downstream flow in the main-stem subbasins for March (greatest decrease in the Main Stem Upper subbasin of $3.5 \mathrm{ft}^{3} / \mathrm{s}$ or 3.1 percent) and September (greatest decrease in the Main Stem Lower subbasin of $0.87 \mathrm{ft}^{3} / \mathrm{s}$ or 1.3 percent). Scenario 4C with increased residential-area recharge resulted in the greatest increase in cumulative downstream flow for the Main Stem Upper subbasin of $2.1 \mathrm{ft}^{3} / \mathrm{s}$ (1.8 percent) for March and $1.1 \mathrm{ft}^{3} / \mathrm{s}$ (6.2 percent) for September. Year 2030 water use with basecase land use (scenario 2) resulted in the greatest increase in cumulative downstream flow for the Main Stem Upper subbasin of $1.8 \mathrm{ft}^{3} / \mathrm{s}$ (1.6 percent) for March and $1.0 \mathrm{ft}^{3} / \mathrm{s}$ (6.1 percent) for September, reflecting the increase in wastewater-return flows. Overall, when 2030 water use was combined with 2030 land use-simulated as decreased commercial-area recharge alone (scenario 4A) or decreased commercial- and residential-area recharge (scenario 4B) - cumulative downstream flow in the main stem decreased in March, as a result of decreased recharge that was greater in magnitude than increased streamflow from wastewater-return flows, and increased in September as a result of wastewater-return flows that were greater than decreased recharge.

Changes in monthly average streamflow from individual Assabet River subbasins varied considerably depending on water-use distributions (fig. 7). Year 2030 water use with basecase land use (scenario 2) caused both decreased and increased streamflow among the subbasins. Simulated increases resulted from increased septic-system return flow and WWTF discharge; decreases were associated with greater consumptive use and withdrawals for public supply. Decreased March streamflow occurred in Cold Harbor and Howard Brooks, Fort Meadow Brook, Fort Pond Brook, and Taylor Brook subbasins; the greatest decrease was $0.11 \mathrm{ft}^{3} / \mathrm{s}$ (less than 1 percent) in Fort Meadow Brook (table 3; scenario 2). Increased March streamflow occurred in the Main Stem Upper and Lower and Nashoba Brook subbasins; the greatest increase was $1.7 \mathrm{ft}^{3} / \mathrm{s}$ (4.6 percent) in the Upper subbasin. Decreased September streamflow occurred in Cold Harbor and Howard Brooks, Fort Meadow Brook, and Main Stem Headwaters subbasins. The greatest decrease of $0.16 \mathrm{ft}^{3} / \mathrm{s}$ (39 percent) in September was simulated for the Fort Meadow Brook subbasin. The greatest increase in September streamflow was $1.1 \mathrm{ft}^{3} / \mathrm{s}$ (8.4 percent) in the Main Stem Upper subbasin in scenario 2 .

Scenarios 3A, 3B, 4A, and 4B included decreased commercial- or commercial- and residential-area recharge with basecase water use. These scenarios resulted in decreased streamflows for most individual subbasins for March. Results for the Main Stem Headwaters subbasin could have been affected by the location of the A-1 Impoundment (fig. 1A) and by the way the impoundment was represented in the model; therefore, the changes in simulated streamflow for September (less than $0.1 \mathrm{ft}^{3} / \mathrm{s}$ for all scenarios) may not be representative of actual conditions. The model water-budget error (inflows minus outflows) was greatest for the Main Stem Headwaters subbasin in September for scenarios 3A and 4A. Changes in water budgets are shown in appendix 4 . The greatest decreased March streamflows were in the Main Stem Headwaters, Fort Meadow Brook, Hop Brook, and Stirrup Brook subbasins. The greatest decrease in streamflow in March of $0.33 \mathrm{ft}^{3} / \mathrm{s}$ (6.1 percent) occurred in Stirrup Brook subbasin for scenario 3B (table 3). For September, streamflows changed depending on the subbasin and the season. The Main Stem Headwaters subbasin had an increase in September streamflow of $0.10 \mathrm{ft}^{3} / \mathrm{s}$ (19 percent) for scenario 3A (table 3). The September increases in streamflows were due to increased return flow (scenarios 4A and 4B); the greatest increase was $0.99 \mathrm{ft}^{3} / \mathrm{s}$ (7.9 percent) in the Main Stem Upper subbasin (table 3). The greatest decreases in September streamflows occurred in Fort Meadow Brook, Cold Harbor and Howard Brooks, Fort Pond Brook, Main Stem Headwaters, and Taylor Brook subbasins, particularly $0.30 \mathrm{ft}^{3} / \mathrm{s}$ (76 percent) in Fort Meadow Brook and $0.10 \mathrm{ft}^{3} / \mathrm{s}$ (20 percent) in Cold Harbor and Howard Brooks subbasins for scenario 4B (table 3). 


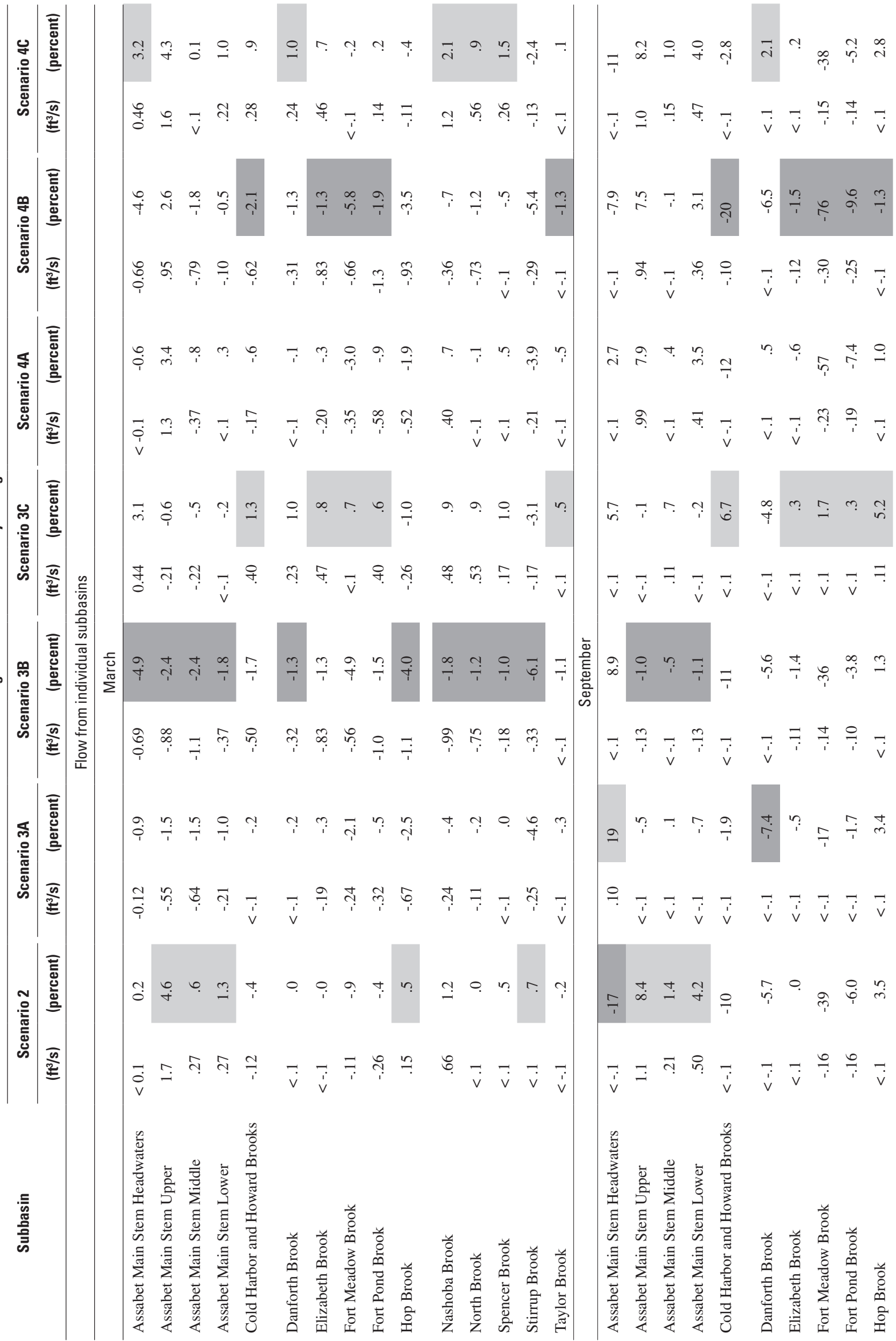




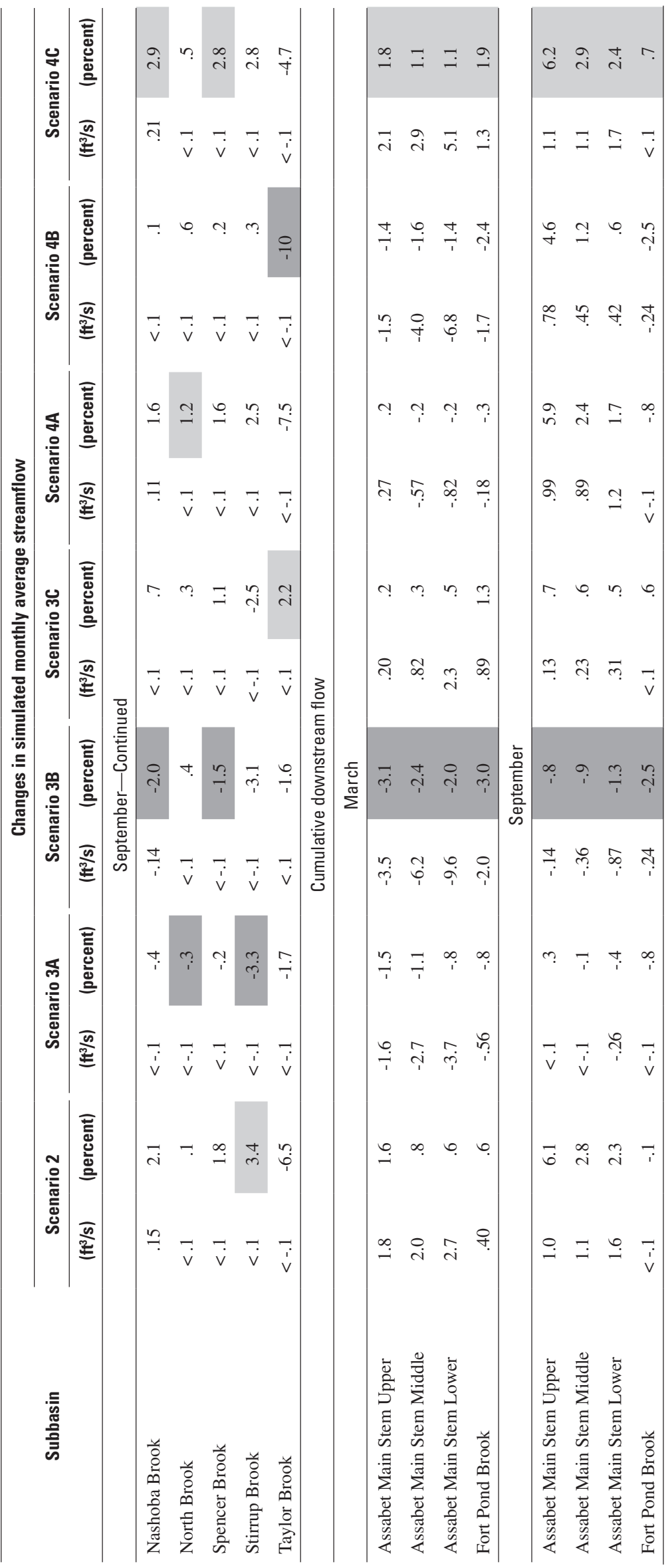


Results for individual subbasins for scenarios $3 \mathrm{C}$ and 4C, which include increased residential-area recharge, also were varied. Changes in March streamflows were increases for Main Stem Headwaters (3C and 4C), Upper (4C), and Nashoba Brook (3C and 4C) subbasins. The greatest increase of $1.6 \mathrm{ft}^{3} / \mathrm{s}$ (4.3 percent) occurred in the Main Stem Upper subbasin in scenario 4C. Decreases in streamflow occurred in March for Stirrup Brook, Hop Brook, and Fort Meadow Brook subbasins; the greatest decrease of $0.17 \mathrm{ft}^{3} / \mathrm{s}$ (3.1 percent) occurred in Stirrup Brook subbasin in scenario 3C. The decrease in streamflows probably was due to the greater decrease in recharge from commercial development than the increase in recharge from residential development in these subbasins. For September, increased residential recharge alone (with basecase water use, scenario 3C) caused the greatest increase in streamflows of less than $0.1 \mathrm{ft}^{3} / \mathrm{s}$ (6.7 percent) in Cold Harbor and Howard Brooks subbasin.

\section{Major Results: Assabet River Basin}

The effects of year 2030 land- and water-use change on streamflows in the Assabet River Basin were found to depend upon several factors, including the time of year, the hydrologic position of a subbasin in the larger basin, and the amount of new commercial and residential development projected for a subbasin. Results of model simulations indicate that the greatest decreases in streamflow, compared to the basecase, can be expected to occur in September, when streamflows are naturally at their lowest level. For March streamflows, decreases were less than 6.1 percent in all subbasins under all scenarios (table 3).

The largest September decreases in simulated streamflow occurred in tributary and headwaters subbasins. For example, Fort Meadow Brook, Cold Harbor and Howard Brooks, and the Assabet Main Stem Headwaters subbasins had simulated decreases of 76, 21, and 17 percent, respectively (fig. 13A). These large decreases can be attributed to projected 2030 changes in either water use (scenario 2) or water use and land use combined (scenario 4B). Although changes in land use alone (scenarios $3 \mathrm{~A}$ and $3 \mathrm{~B}$ ) caused simulated streamflow decreases in 8 of the remaining 12 subbasins, in only one case was the decrease greater than 5 percent (scenario 3A; Danforth Brook; 7.4 percent). In addition, September streamflow decreases in the main stem Assabet subbasins (Upper, Middle, and Lower) were all relatively small (less than 5 percent). The modest response of the main-stem subbasins to projected development likely reflects the buffering effect on low streamflows provided by inflows from upstream subbasins, as well as the relative lack of developable land in the main-stem Assabet River corridor compared to that in the tributary subbasins.

Increases in simulated September streamflow also occurred for projected 2030 conditions; the largest were simulated for the main-stem subbasins. The increases are due mainly to increased discharges of treated effluent from wastewater-treatment facilities on the main stem. Simulated streamflows leaving the Assabet Main Stem Upper subbasin, for example, increased by 8.4 percent in 2030 under the wateruse-change scenario (scenario 2). The substantial fraction (55 percent) of average September streamflow consisting of wastewater in the Assabet Main Stem Upper subbasin under basecase conditions (DeSimone, 2004) is therefore likely to increase if present trends in water use continue through 2030 (fig. 12A). Increased September streamflow in subbasins other than the main stem, that is, increased flow due to factors other than increased discharge from WWTFs, resulted from increased septic-system return flow from new development or increased recharge associated with the simulation of new residential development, or both.

Finally, inherent uncertainties related to the effects of residential development on ground-water recharge were accommodated by the use of two alternative estimates of change in residential-area recharge in the scenarios incorporating projected 2030 land-use change. The first alternative (scenarios 3B and 4B) assigned a recharge change of -10 percent to undeveloped land undergoing residential development, whereas the second alternative (scenarios $3 \mathrm{C}$ and $4 \mathrm{C}$ ) assigned a recharge change of +10 percent. These alternatives served to bracket estimates of 2030 streamflow in the scenarios that incorporated land-use change. The effect of this uncertainty was greatest in the subbasins projected to the have the greatest degree of residential development and was generally greater in the tributary and headwaters subbasins than in the main-stem subbasins.

Also, some of the changes in September simulated streamflow from the tributary and headwater subbasins were quite small in absolute terms (less than $0.1 \mathrm{ft}^{3} / \mathrm{s}$; table 3 ). Hence, the relative (percent) changes for basins with very low simulated streamflows (less than $0.1 \mathrm{ft}^{3} / \mathrm{s}$ ) were interpreted with caution.

Overall March streamflow changes in the Assabet River Basin were not dominated by any one change in land or water use. However, changes in 2030 land use alone, water use alone, or a combination of land use and water use were important to March streamflow changes in individual subbasins. Most changes in streamflows in September, however, were affected to a greater degree by 2030 water use specific to each subbasin. Simulation of a particular scenario did not cause the same effect in all subbasins. It is uncertain precisely how land will be developed in the future, and the ranges of greatest decrease to greatest increase for both March and September streamflow changes (table 3) are indications of the potential change that could result, depending on how land is developed in a particular subbasin. The results summarized in table 3 could be used by water managers to determine the potential year 2030 changes to which a particular subbasin is most sensitive and whether those potential changes are of consequence to local or state goals or regulatory limits. 

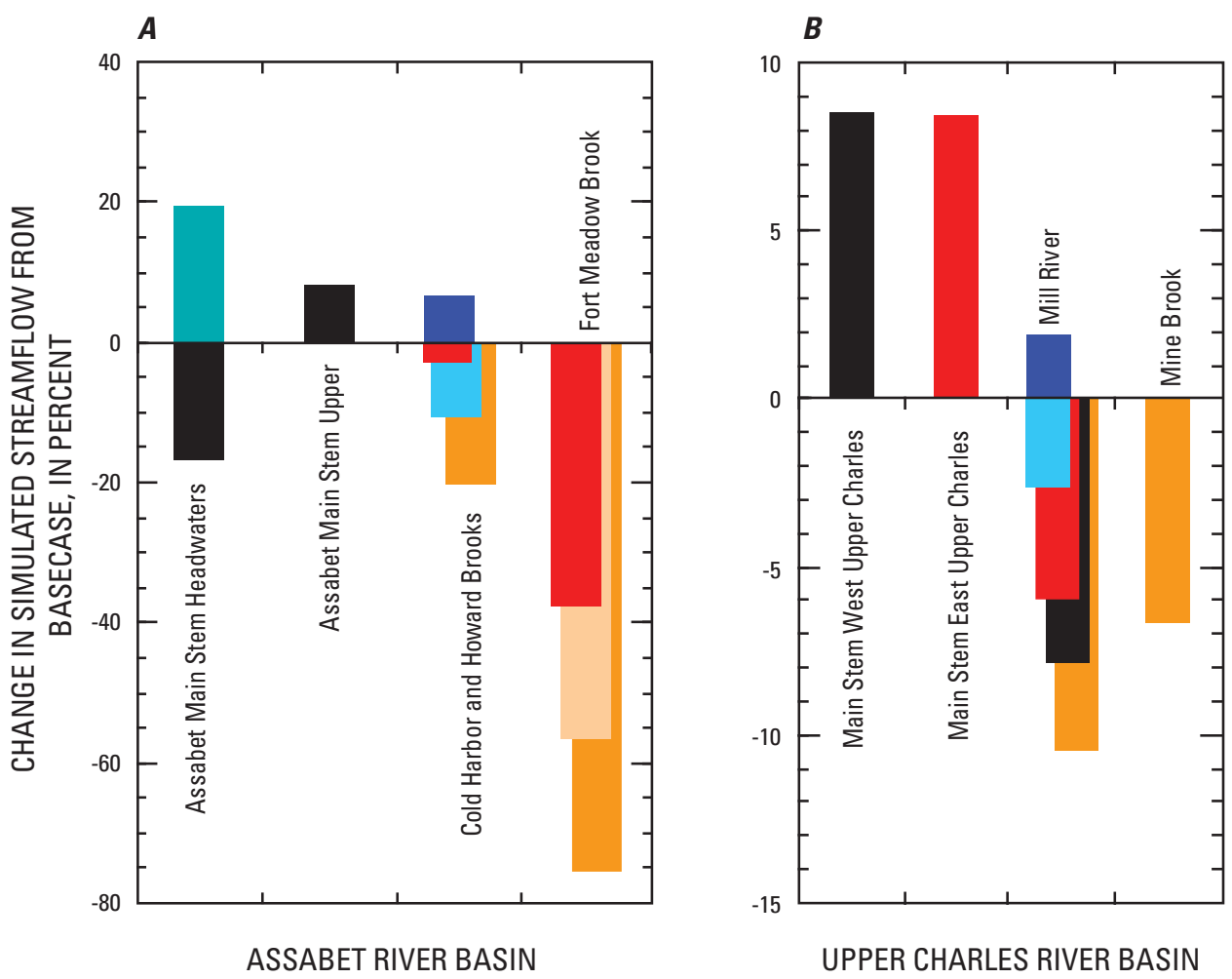

\section{EXPLANATION}

\section{Scenario}

2: Basecase land use, 2030 water use

3A: Basecase water use, 2030 land use, and decreased commercial-area recharge by 50 percent

- 3B: Basecase water use, 2030 land use, decreased commercial-area recharge by 50 percent, and decreased residential-area recharge by 10 percent

- 3C: Basecase water use, 2030 land use, decreased commercial-area recharge by 50 percent, and increased residential-area recharge by 10 percent

4A: 2030 land use, 2030 water use, and decreased commercial-area recharge by 50 percent

4B: 2030 land use, 2030 water use, decreased commercial-area recharge by 50 percent, and decreased residential-area recharge by 10 percent

4C: 2030 land use, 2030 water use, decreased commercial-area recharge by 50 percent, and increased residential-area recharge by 10 percent

Figure 13. Greatest percentage change in simulated streamflow from basecase conditions for seven scenarios in (A) Assabet River and (B) Upper Charles River subbasins, eastern Massachusetts. 


\section{Upper Charles River Basin}

Simulated streamflow in the Upper Charles River Basin showed a range of responses to year 2030 water- and landuse conditions. Average annual streamflow changes were comparatively small, although greater than those for the Assabet River Basin; the average decrease in streamflows was $0.69 \mathrm{ft}^{3} / \mathrm{s}$, and the average increase in streamflows was $0.39 \mathrm{ft}^{3} / \mathrm{s}$, for all scenarios and subbasins (fig. 9). Results for year 2030 water use, scenario 2, typify most of the changes in streamflow for the other scenarios; that is, increased water use affected streamflows in most subbasins of the Upper Charles River Basin. Most average annual increases or decreases in streamflow from individual subbasins were consistent by subbasin (figs. 8 and 9). The Mill River and Main Stem West subbasins had decreased annual average streamflows for all scenarios as a result of increased water use and reduced recharge due to new development (fig. 9). Increased residential-area recharge in scenarios $3 \mathrm{C}$ and $4 \mathrm{C}$ did, to an extent, counteract streamflow decreases associated with water use, but not enough to cause an increase in streamflow. Streamflows decreased in Bogastow Brook subbasin for all scenarios except for a small increase in scenario 3C (increased recharge from residential development). Again, decreased streamflow was due to increased water use and new development. However, increased streamflow in Bogastow Brook subbasin due to increased residential-area recharge in scenario 3C was minor. Streamflows from Chicken Brook subbasin generally increased for each scenario because no production wells are in this subbasin, and the increased streamflow was due to increased return flow from residential development (fig. 9). For the Main Stem East subbasin, only the scenario that included decreased commercial- and residential-area recharge (3B) showed a decrease in annual average streamflow. Hopping Brook and Mine Brook subbasins show the greatest variability in streamflow change by scenario.

\section{Wastewater Flows}

Treated-wastewater discharge to the surface-waterflow system accounted for larger proportions of simulated streamflow in the Upper Charles main stem subbasins in
September than annually or in March. In the main-stem subbasins, changes in wastewater discharge from all WWTFs increased for each month (table 4). Simulated year 2030 wastewater accounted for, on average, 16 and 22 percent of simulated September streamflow out of the Upper Charles Main Stem West and East subbasins, respectively (fig. 12B), whereas basecase values were 14 percent for the Main Stem West and 18 percent for the Main Stem East subbasins, respectively (fig. 12B). In March, when overall streamflows were much higher, wastewater accounted for only 5 and 7 percent of simulated streamflow out of the Upper Charles Main Stem West and East subbasins, respectively (fig. 12B). Basecase values for March were 5 and 6 percent for the Main Stem West and East subbasins, respectively. Because the September proportion of WWTF discharge was greater than that of March, WWTF discharges were more important to main-stem streamflows in September than in other months. WWTF discharge was a greater proportion of main-stem streamflow in the East subbasin than in the West subbasin; as a result, WWTF discharge became a greater percentage of total streamflow with distance downstream. This may have been due to the distribution of wastewater discharges along the main-stem Upper Charles River-the largest of two discharges was near the downstream end of the model area.

\section{Streamflow Changes by Subbasin}

Changes in March cumulative downstream flow in the main-stem subbasins were similar by subbasin and scenario (fig. 10). The changes in simulated monthly average streamflow and the changes as a percentage of basecase streamflow for each subbasin and scenario are shown in table 5. Scenarios 3B and 4B, with decreased simulated recharge from commercial and residential land-use change, showed decreases in main-stem cumulative downstream flow for March (greatest decrease in the Main Stem West subbasin of $3.8 \mathrm{ft}^{3} / \mathrm{s}$ or 2.4 percent in scenario 3B; table 5) and September (greatest decrease in the Main Stem West subbasin of $0.62 \mathrm{ft}^{3} / \mathrm{s}$ or 2.1 percent in scenario $3 \mathrm{~B}$; table 5). For scenarios $3 \mathrm{C}$ and $4 \mathrm{C}$, with increased simulated residentialarea recharge, the greatest increase in streamflow in the Main Stem East subbasin was $1.7 \mathrm{ft}^{3} / \mathrm{s}$ (0.7 percent) for scenario $3 \mathrm{C}$

Table 4. Changes in simulated monthly average wastewater discharge from basecase conditions for main-stem subbasins, Upper Charles River Basin, eastern Massachusetts.

$\left[\mathrm{ft}^{3} / \mathrm{s}\right.$, cubic feet per second]

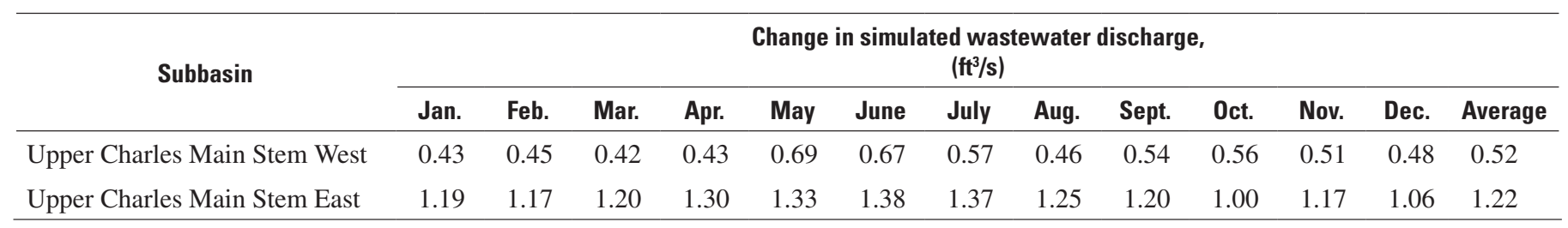




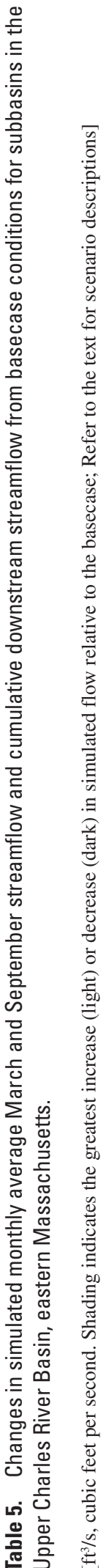




in March and $0.41 \mathrm{ft}^{3} / \mathrm{s}(0.8$ percent) for scenario $3 \mathrm{C}$ in September. Year 2030 water use with basecase land use caused main-stem March streamflows to decrease by less than 1 percent for both subbasins and September streamflows to increase - the greatest increase was in the West subbasin $\left(0.70 \mathrm{ft}^{3} / \mathrm{s}\right.$ or 2.3 percent). Year 2030 land-use changes had the greatest influence on main-stem streamflows in March and year 2030 water-use changes had the greatest influence on main-stem streamflows in September.

Scenario 2 (basecase land use and year 2030 water use) for individual Upper Charles River subbasins resulted in decreased simulated streamflow for Mine Brook, Mill River, and Bogastow Brook subbasins in March and for all subbasins in September (fig. 11). Year 2030 water use caused decreased March streamflow in Mill River, Mine Brook, and Bogastow Brook subbasins. The greatest March decrease was $0.79 \mathrm{ft}^{3} / \mathrm{s}$ ( 2.4 percent) in Mine Brook. Increased streamflows probably resulted from increased return flows, including WWTF discharges, and decreased streamflows from greater consumptive use and withdrawals for public supply. The greatest March increase was $0.73 \mathrm{ft}^{3} / \mathrm{s}$ ( 2.4 percent $)$ in the Main Stem East subbasin. Year 2030 water use caused decreased September streamflows in Mill River and Mine Brook subbasins, with the greatest decrease of $1.0 \mathrm{ft}^{3} / \mathrm{s}$ (7.8 percent) in the Mill River subbasin. Increased September streamflows occurred in the main-stem subbasins; the greatest increase of $1.1 \mathrm{ft}^{3} / \mathrm{s}$ (8.5 percent) was in the Main Stem West subbasin.

Scenarios 3A, 3B, 4A, and 4B, which included decreased commercial or commercial- and residential-area recharge, resulted in decreased streamflows in most subbasins for March and September (table 5). The greatest decrease of $1.8 \mathrm{ft}^{3} / \mathrm{s}$ (5.3 percent) occurred in Mine Brook subbasin for scenario 4B. Of the subbasins that had decreased September streamflows, Mill River had the greatest decrease of $1.4 \mathrm{ft}^{3} / \mathrm{s}$ (11 percent).

Scenarios 3C and 4C, which included increased residential-area recharge, caused mostly increased streamflows for March and September. The greatest increase for March $\left(1.1 \mathrm{ft}^{3} / \mathrm{s}\right.$ or 3.7 percent $)$ and the greatest increase for September $\left(0.77 \mathrm{ft}^{3} / \mathrm{s}\right.$ or 8.5 percent) occurred in Main Stem East subbasin for scenario $4 \mathrm{C}$.

March streamflow changes, although more variable by subbasin than the average annual results, were mostly characterized by results from year 2030 land use alone (scenarios 3A-C; fig. 11). The patterns of streamflow change for each subbasin were similar for March and September. Mine Brook and Mill River subbasins had decreased streamflows for each scenario, except scenario 3C with 2030 land use where residential-area recharge was increased. In March and September, projected year 2030 water-use change resulted in decreased streamflows in Mine Brook, Mill River, Bogastow Brook, and Hopping Brook subbasins. In these same subbasins, changes in streamflows from year 2030 land-use changes, which resulted in decreased recharge, resulted in even greater decreased streamflow. When recharge was increased, the decrease in streamflow was lessened. A similar effect occurred for September streamflow changes in individual subbasins in the Main Stem West, East, and Chicken Brook subbasins. In these subbasins, year 2030 water use alone caused increased streamflows (scenario 2), year 2030 land use caused mostly decreased streamflows (scenarios 3A, 3B, and 3C), and year 2030 water use and land use combined (scenarios 4A, 4B, and 4C) caused the increased streamflows from water-use change to offset the decreased streamflow from land-use change.

\section{Major Results: Upper Charles River Basin}

The effects of year 2030 water and land use on streamflows in the Upper Charles River Basin varied substantially by subbasin because of season, hydrologic position, and projected basin-specific water- and land-use patterns. Simulated changes in March streamflows for 2030 in the Upper Charles River Basin were within 6 percent of the basecase for all scenarios and subbasins (table 5). Decreases in simulated September streamflows for year 2030 were greater than decreases in March but substantially less than the September decreases simulated for the Assabet River Basin. Only two subbasins in the Upper Charles River Basin had decreases greater than 5 percent (11 percent for Mill River subbasin and 6.6 percent for Mine Brook subbasin; scenario 4B; fig. 13B). A comparison of scenarios 2, 4B, and $4 \mathrm{C}$ indicates that changes in both water use and land use contributed to the simulated 11 percent decrease in streamflows in the Mill River subbasin: water use alone (scenario 2) caused a decrease of 7.8 percent, and land use alone caused both a decrease of 2.6 percent (scenario 3B) and an increase of 1.9 percent (scenario 3C). This comparison revealed that year 2030 water use was important to simulated streamflows from Mill River subbasin. Depending on the effect that residential-area development has on recharge rates, along with 2030 water use, the following decreases in streamflow from Mill River subbasin attributable to the effect of 2030 water use could be substantial: a decrease in recharge of 10 percent in residential areas (scenario 4B) could cause an 11 percent decrease in streamflow, and an increase in recharge of 10 percent in residential areas (scenario $4 \mathrm{C}$ ) could cause a decrease of only 5.9 percent.

Increases in simulated 2030 streamflow also occurred in certain scenarios for some subbasins of the Upper Charles River Basin for September conditions. As in the Assabet River Basin, the greatest increases resulted from simulations for the main-stem subbasins; the increases can be attributed to increased discharge of treated effluent from wastewatertreatment facilities. Both the Main Stem West and Main Stem East subbasins were projected to have September streamflow increases of about 8.5 percent. In the case of the West subbasin, this increase could be attributed to water-use change alone (scenario 2), whereas for the East subbasin, both water-use and land-use change may be important (scenarios 4B and 4C). 
As in the Assabet River Basin, it is uncertain how land will be developed in the future. The greatest streamflow changes by scenario for both March and September (table 5) are an indication of the changes that could result, depending on how land is developed in a particular subbasin. The summary in table 5 could be used by water managers to determine the potential year 2030 changes to which a particular subbasin is most sensitive and whether those potential changes are of consequence to local or state goals or regulatory limits.

\section{Simulated Streamflows for Habitat Requirements}

Minimum streamflows are required to maintain a healthy habitat for fish and wildlife; therefore, it is useful to compare model-simulated streamflows to minimum streamflow requirements for habitat protection. Several methods are available that can be used to calculate minimum streamflow requirements; the R2Cross, Wetted Perimeter, and the Range of Variability Approach (RVA) methods are examples. The minimum streamflow requirements determined by these methods represent flows needed to provide a minimum water depth and velocity in the stream channel to maintain a healthy habitat for fluvial fish (Armstrong and others, 2001; Parker and others, 2004).

For this purpose, nonstorm streamflows also were calculated per stream mile and in flow per unit basin area $\left.\left[\left(\mathrm{ft}^{3} / \mathrm{s}\right) / \mathrm{mi}^{2}\right)\right]$ for the subbasins. Simulated mean monthly nonstorm streamflows were calculated for the main-stem river subbasins in both the Assabet River Basin (fig. 14) and Upper Charles River Basin (fig. 15) for March and September. Those figures show simulated mean monthly streamflow for each water- and land-use scenario as a function of distance downstream. Streamflow changes were fairly consistent with distance downstream among the scenarios (figs 16 and 17). In both the Assabet (fig. 16) and the Upper Charles River Basins (fig. 17), scenarios 3A, 3B, 4A, and 4B resulted in decreases in streamflow for March, and scenarios 3A and $3 \mathrm{~B}$ resulted in decreases in streamflow for September with distance downstream.

Simulated mean monthly streamflows per unit basin area for March and September are shown in figures 18 and 19. Simulated cumulative downstream flows for the main-stem Assabet and Upper Charles River subbasins are shown in figures 20 and 21. Comparisons of simulated streamflows with minimum streamflow requirements are complicated by several factors. Model-calculated streamflows could be underestimates or overestimates of actual average monthly streamflows at measurement sites (DeSimone, 2004). Also, simulated streamflows of less than $0.1\left(\mathrm{ft}^{3} / \mathrm{s}\right) / \mathrm{mi}^{2}$ of drainage area could be within the measurement error for streamflow. Minimum streamflows to maintain a healthy fluvial habitat can vary naturally among subbasins and along stream reaches within subbasins. Model-calculated streamflows from the MODFLOW ground-water models are monthly averages of nonstorm streamflow. A mean monthly streamflow for September that is at or near the minimum streamflow requirement may represent mean daily streamflows that are below the minimum streamflow requirement about half the time (DeSimone, 2004). Stormwater flows, which were not simulated, would augment mean daily streamflows some of the time. The changes in flow per unit basin area, even in September, among all scenarios are small relative to proposed guidelines, except for perhaps Fort Meadow Brook subbasin in the Assabet River Basin and Mill River subbasin in the Upper Charles River Basin. 




Figure 14. Simulated mean monthly nonstorm streamflows for $(A)$ March and $(B)$ September for seven scenarios and basecase conditions and the portion that originated as wastewater, Assabet River Basin, eastern Massachusetts. Numbers show locations of wastewater-treatment facility (WWTF) discharges: 1, Westborough WWTF; 2, Marlborough WWTF; 3 , Hudson WWTF; 4, Maynard WWTF; 5, MCI Concord WWTF. 


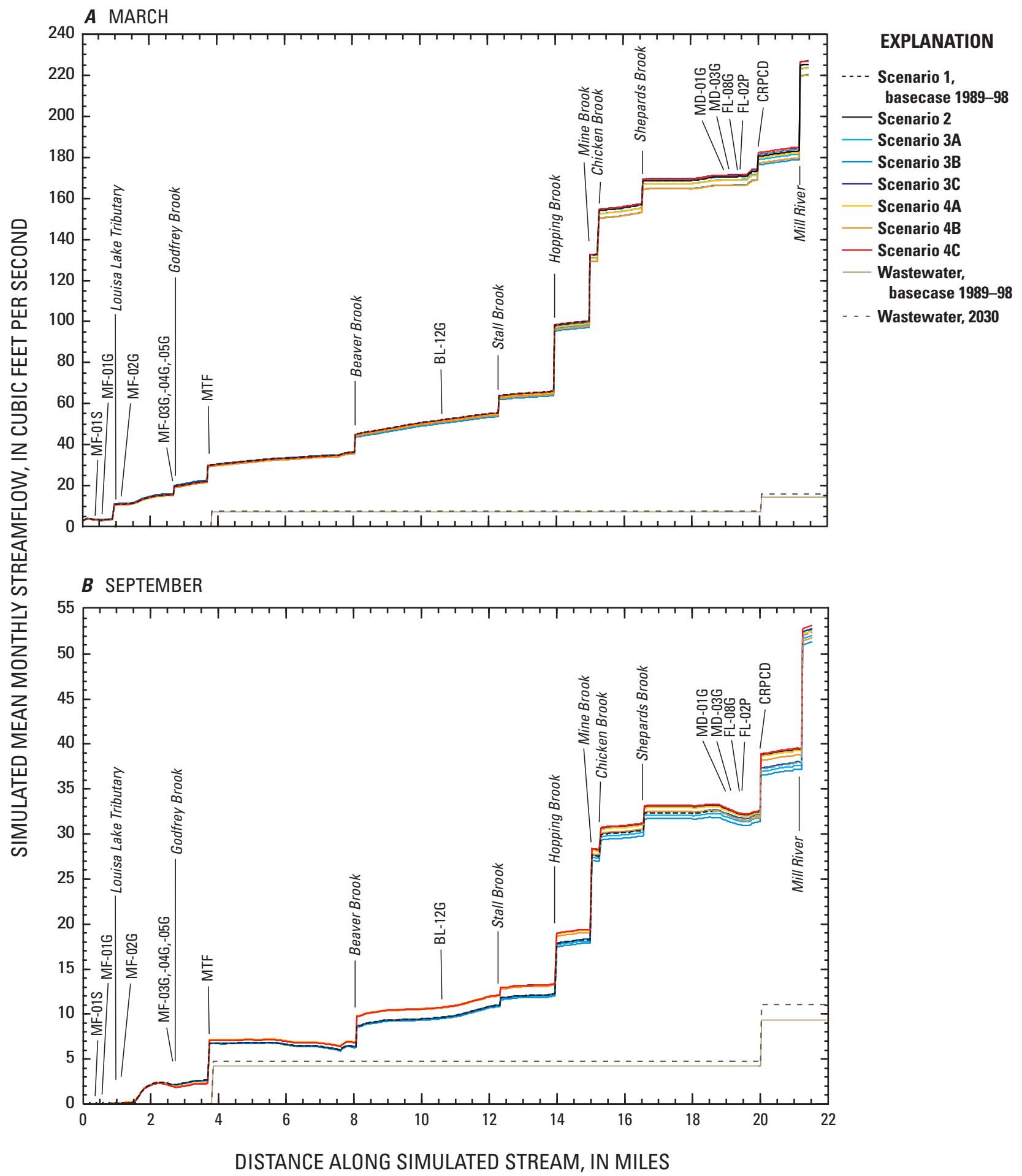

Figure 15. Simulated mean monthly nonstorm streamflows for (A) March and (B) September for seven scenarios and basecase conditions and the portion that originated as wastewater, total nonstorm streamflow and the component of streamflow that originated as wastewater, Upper Charles River Basin, eastern Massachusetts. (MTF, Milford Treatment Facility; CRPCD, Charles River Pollution Control District) 




Figure 16. Changes in simulated mean monthly nonstorm streamflows for (A) March and (B) September from basecase conditions for seven scenarios for subbasins in the Assabet River Basin, eastern Massachusetts. Locations of streams are shown by position of stream names. Numbers show locations of wastewater-treatment facility (WWTF) discharges: 1, Westborough WWTF; 2, Marlborough WWTF; 3, Hudson WWTF; 4, Maynard WWTF; 5, MCI Concord WWTF. 


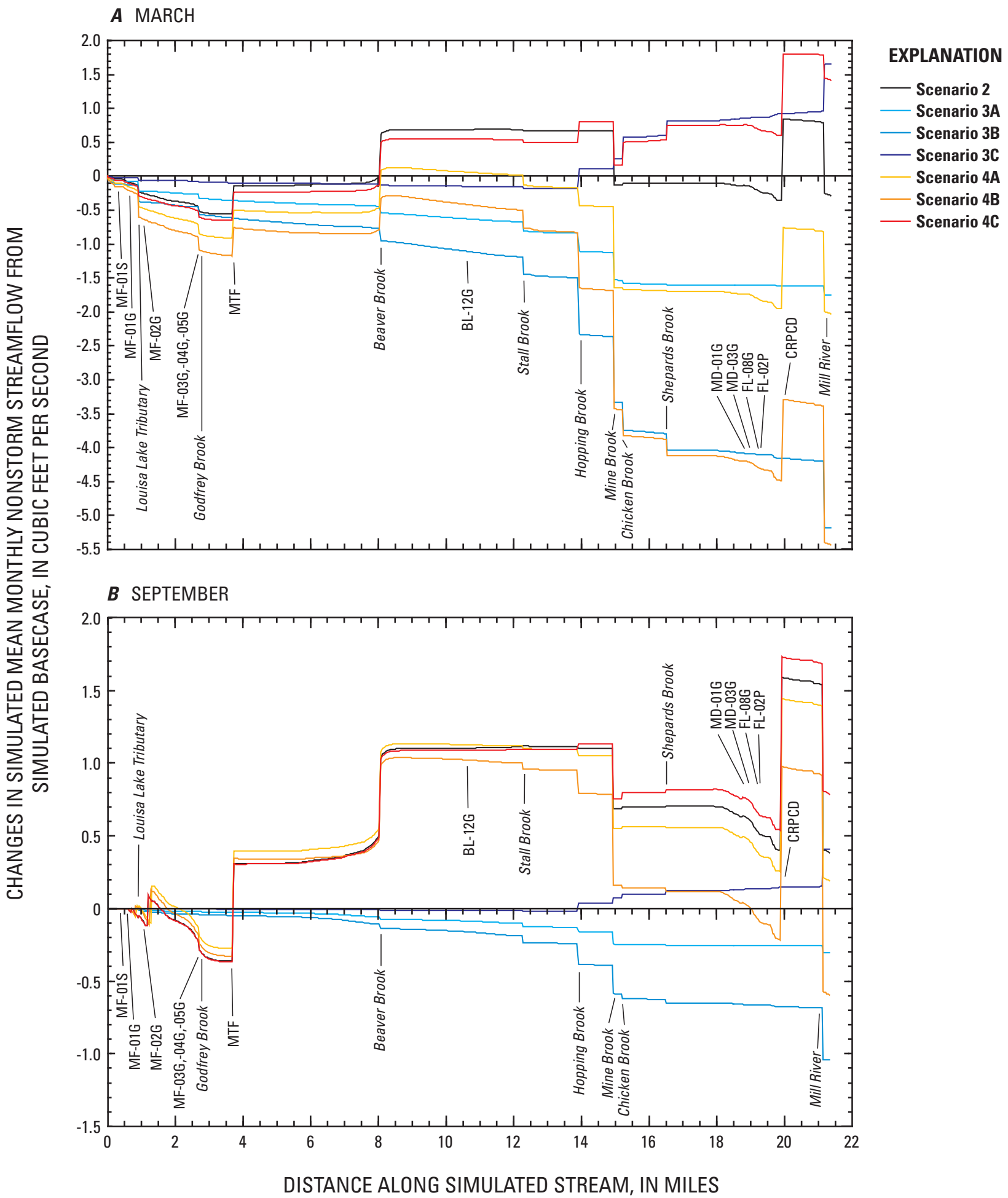

Figure 17. Changes in simulated mean monthly nonstorm streamflows for ( $A$ ) March and (B) September from basecase conditions for seven scenarios for subbasins in the Upper Charles River Basin, eastern Massachusetts. Locations of streams and other discharges are shown by position of stream or facility names. (MTF, Milford Treatment Facility; CRPCD, Charles River Pollution Control District; see figure 1-2B for well locations) 


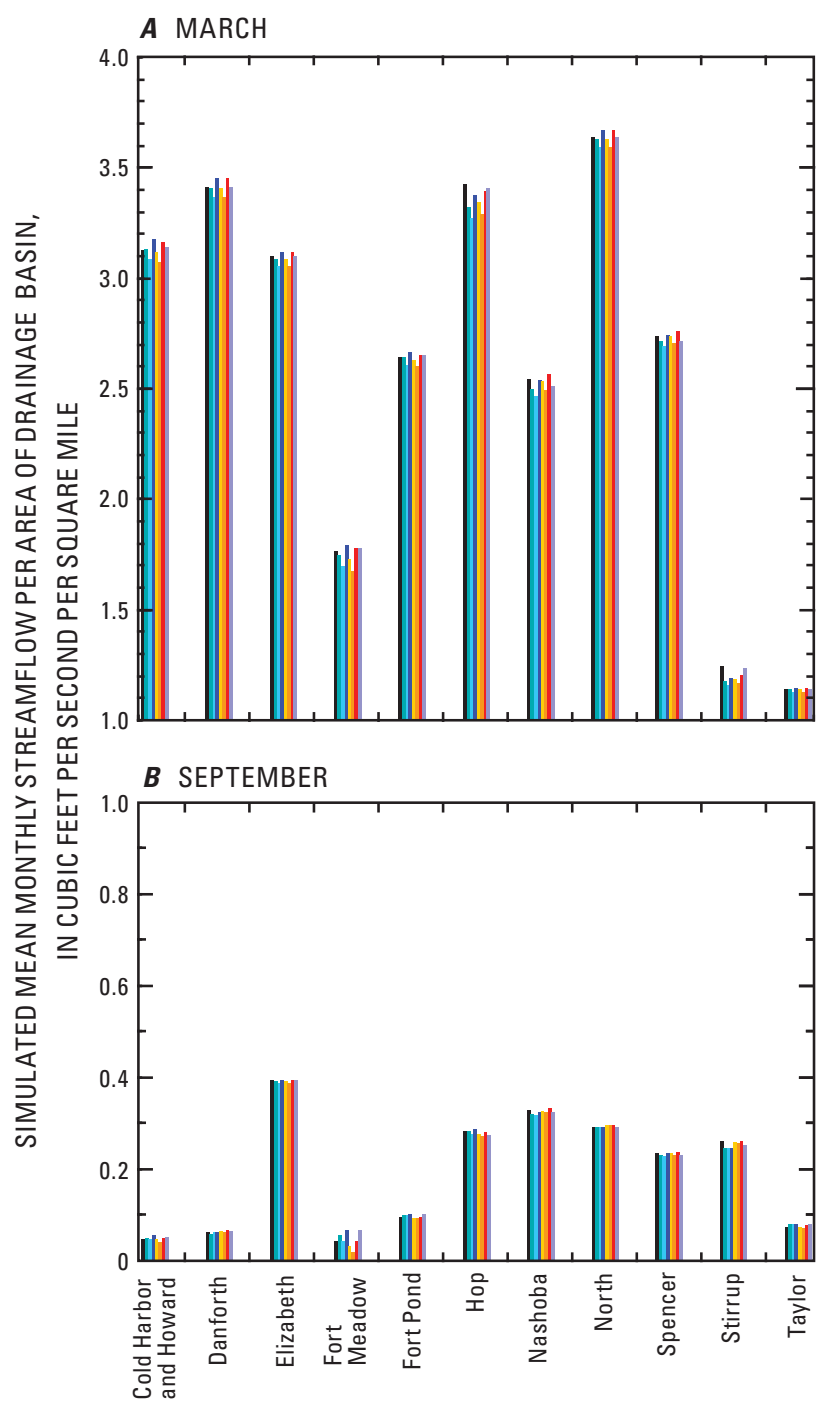

TRIBUTARIES TO ASSABET RIVER

Figure 18. Simulated mean monthly streamflows in cubic feet per second per square mile for $(A)$ March and $(B)$ September for seven scenarios and basecase conditions for individual subbasins in the Assabet River Basin, eastern Massachusetts.

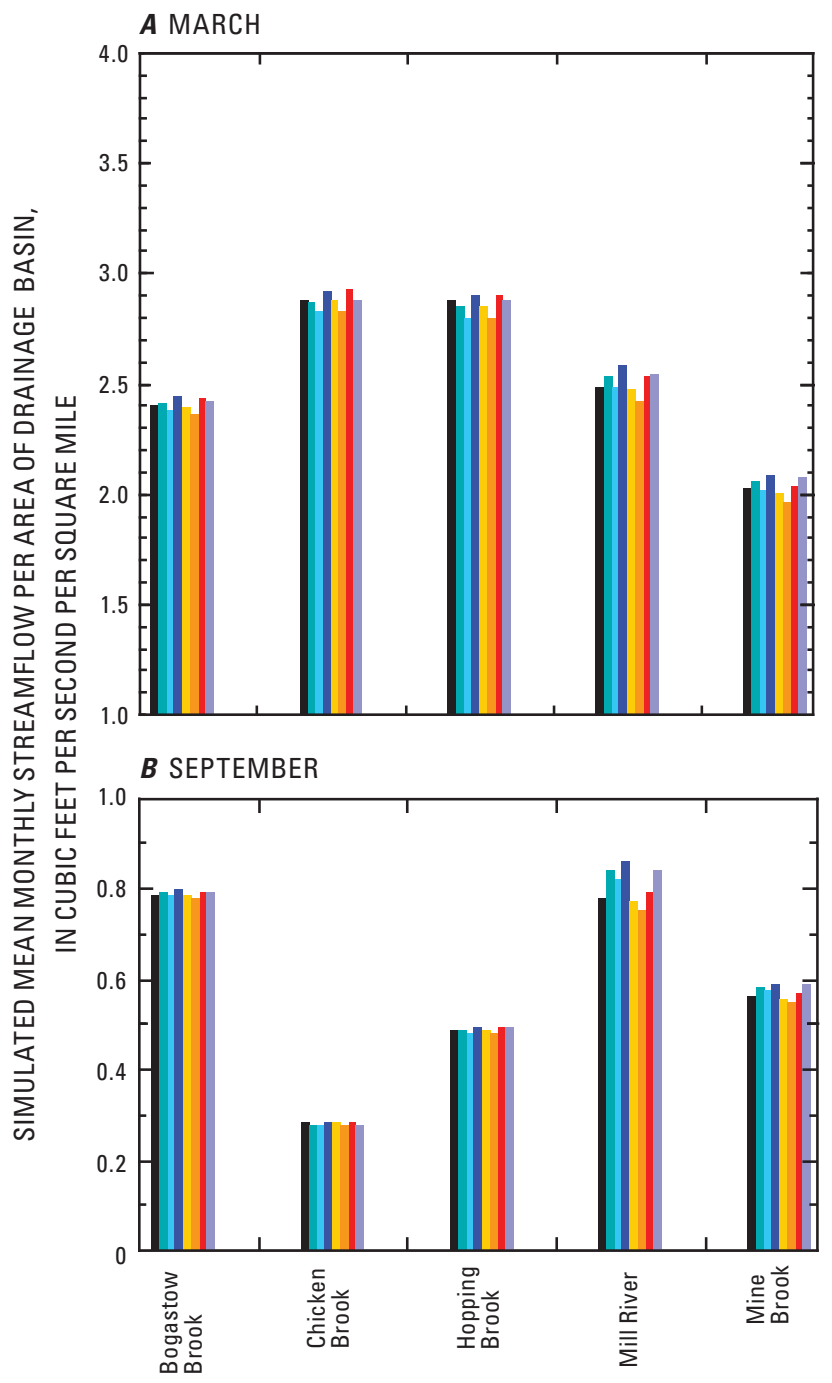

TRIBUTARIES TO UPPER CHARLES RIVER

Figure 19. Simulated mean monthly streamflows in cubic feet per second per square mile for $(A)$ March and $(B)$ September for seven scenarios and basecase conditions for individual subbasins in the Upper Charles River Basin, eastern Massachusetts.

\section{EXPLANATION}

(For figures 18 and 19)

\section{Scenario}

- 2: Basecase land use, 2030 water use

- 3A: Basecase water use, 2030 land use, and decreased commercial-area recharge by 50 percent

3B: Basecase water use, 2030 land use, decreased commercial-area recharge by 50 percent, and decreased residential-area recharge by 10 percent

- 3C: Basecase water use, 2030 land use, decreased commercial-area recharge by 50 percent, and increased residential-area recharge by 10 percent

4A: 2030 land use, 2030 water use, and decreased commercial-area recharge by 50 percent

4B: 2030 land use, 2030 water use, decreased commercial-area recharge by 50 percent, and decreased residential-area recharge by 10 percent

4C: 2030 land use, 2030 water use, decreased commercial-area recharge by 50 percent, and increased residential-area recharge by 10 percent

Basecase 


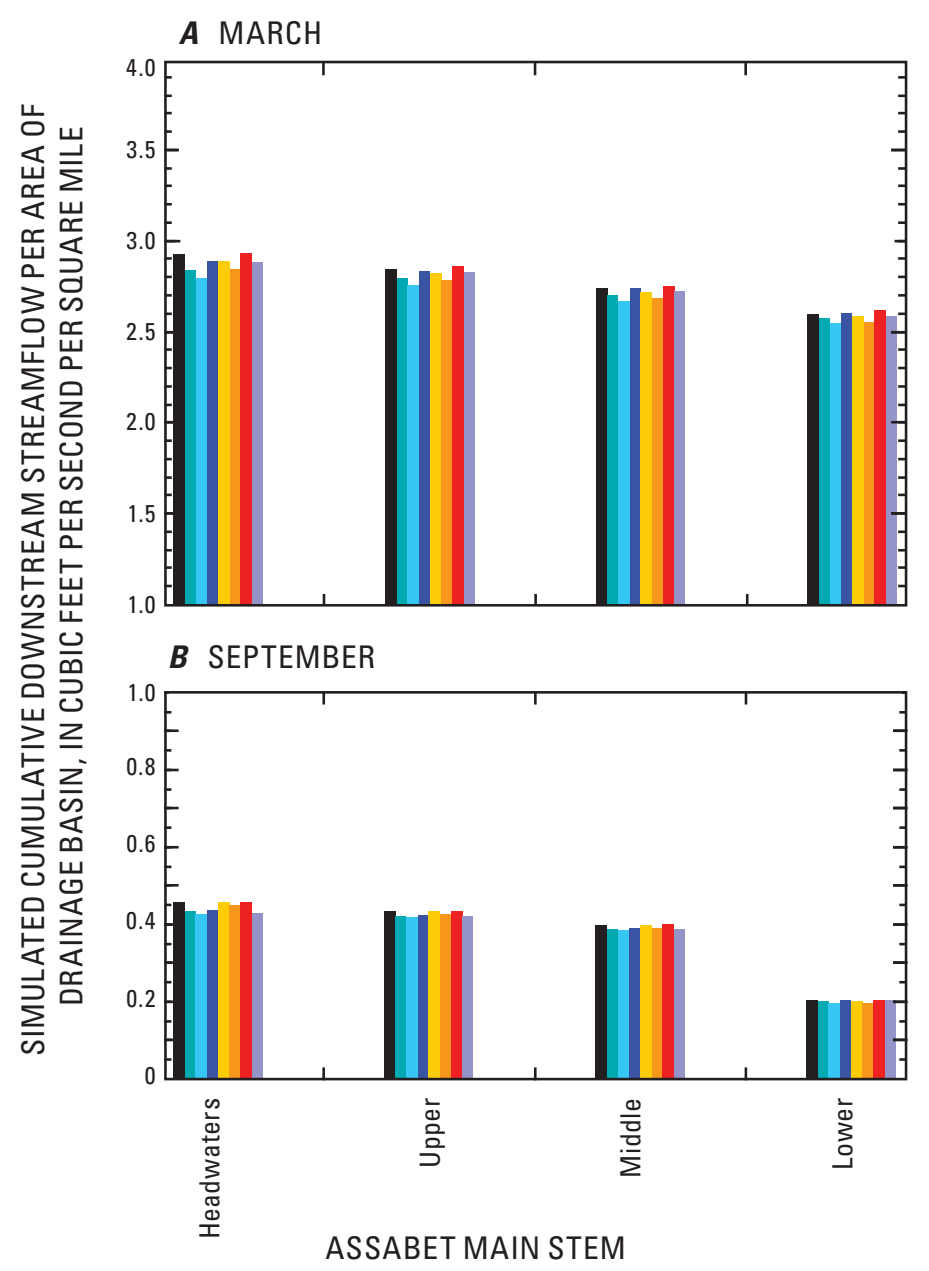

Figure 20. Simulated cumulative downstream streamflow in cubic feet per second per square mile for $(A)$ March and (B) September for seven scenarios and basecase conditions for Main Stem subbasins in the Assabet River Basin, eastern Massachusetts.

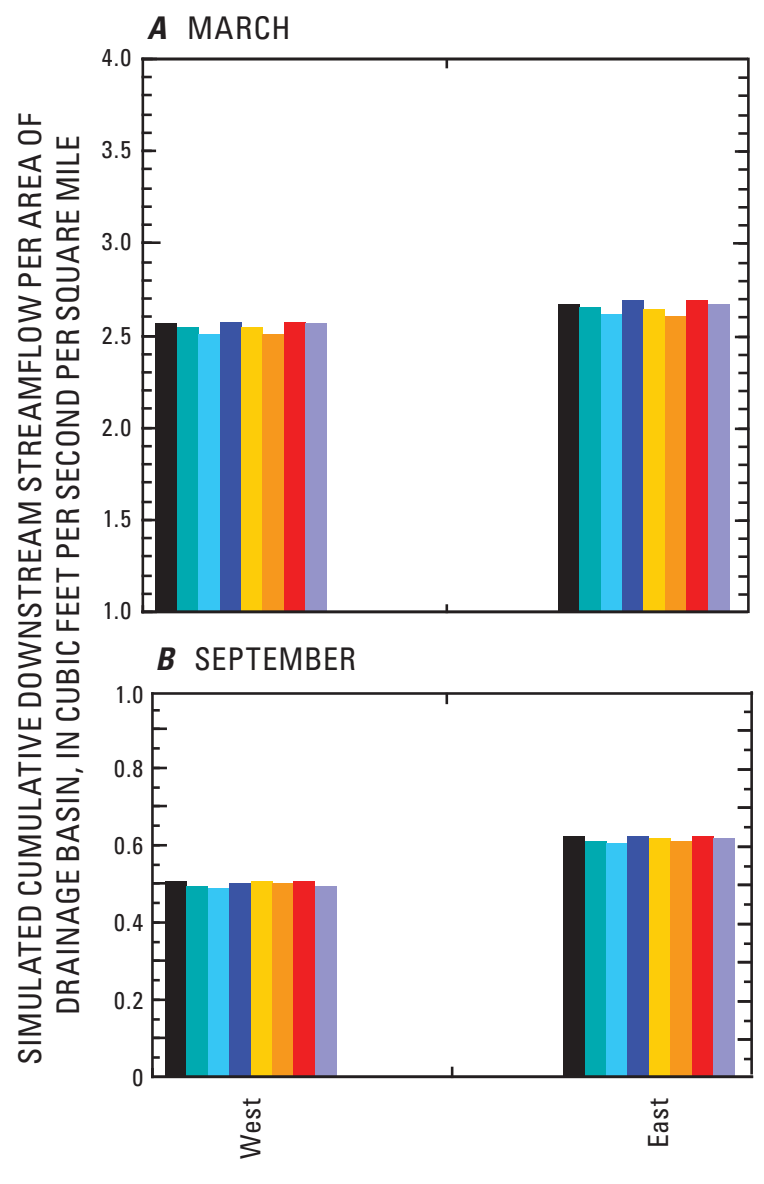

UPPER CHARLES RIVER MAIN STEM

Figure 21. Simulated cumulative downstream streamflow in cubic feet per second per square mile for (A) March and $(B)$ September for seven scenarios and basecase conditions for Main Stem subbasins in the Upper Charles River Basin, eastern Massachusetts.

\section{EXPLANATION}

Scenario

\section{(Figures 20 and 21)}

2: Basecase land use, 2030 water use

3A: Basecase water use, 2030 land use, and decreased commercial-area recharge by 50 percent

3B: Basecase water use, 2030 land use, decreased commercial-area recharge by 50 percent, and decreased residential-area recharge by 10 percent

- 3C: Basecase water use, 2030 land use, decreased commercial-area recharge by 50 percent, and increased residential-area recharge by 10 percent

4A: 2030 land use, 2030 water use, and decreased commercial-area recharge by 50 percent

4B: 2030 land use, 2030 water use, decreased commercial-area recharge by 50 percent, and decreased residential-area recharge by 10 percent

- 4C: 2030 land use, 2030 water use, decreased commercial-area recharge by 50 percent, and increased residential-area recharge by 10 percent

Basecase 


\section{Assessment of Potential Effects of Low-Impact Development in Hop Brook Subbasin, Assabet River Basin-A Test Case}

Low-impact development (LID) practices are intended to minimize hydrologic alterations in areas of development. The Hop Brook subbasin was chosen as a test case for the simulation of the effects of LID practices because of its location in the headwaters of the Assabet River Basin and the amount of land available for future commercial development (fig. 22). Hop Brook subbasin has a total area of about 5,025 acres. Eighteen percent (920 acres) of the Hop Brook subbasin is zoned for future commercial development, and 22 percent ( 203 acres) of that developable area is projected to be developed by year 2030 .

Commercially developed areas typically have lower recharge rates than areas developed for residential use (Zarriello and Ries, 2000). For purposes of this study, the changes in recharge from basecase due to implementation of LID practices in new commercial development were assumed to resemble changes from basecase associated with traditional residential development (change of 10 percent). That is, instead of decreasing recharge by 50 percent in areas of future commercial development, recharge was increased and decreased by 10 percent, as was done for areas of future residential development. Only the effects of land-use change were simulated in the Hop Brook LID scenarios. The results of the simulation showed the effects of land-use change on nonstorm base flow. Development with LID likely leads to higher base flow than development without LID (traditional), but development without LID also is likely to lead to higher total streamflow because non-LID development leads to increased runoff (increased storm-generated streamflow).

The effects of LID practices on changes in streamflow out of Hop Brook subbasin were simulated for areas of commercial development by using the change-in-recharge rates that were developed for residential areas. Six additional LID scenarios were simulated that combined characteristics of the land-use scenarios $3 \mathrm{~B}$ and $3 \mathrm{C}$ (previously discussed) and the percentage of commercial land area developed by 2030 - 22 percent (the amount projected to be developed by year 2030; table 1) and 100 percent. Two types of comparisons were made to assess the effects of LID practices: the change in streamflow between land developed by traditional practices (assumed 50-percent decrease in recharge) and that by LID practices (10 percent change in recharge) and (2) the change in streamflow between individual LID scenarios and the basecase or undeveloped land use.

Results from the first set of comparisons show that, in the LID scenarios, March streamflow from Hop Brook subbasin was higher by 2.9 percent than the non-LID streamflow (table 6), with 22 percent of commercial-land area developed in scenario 3C. September streamflow was higher by 1.8 percent for the LID scenarios based on scenario $3 \mathrm{~B}$ and lower than about 3.0 percent for the LID scenarios, compared to the non-LID streamflow, based on scenario 3C (table 6), both with 22 percent of commercial-land area developed. The change in simulated September streamflows was less than $0.1 \mathrm{ft}^{3} / \mathrm{s}$. Changes in ground-water storage and flow between subbasins may account for the decrease. Also, recharge was not applied in the model from June through September, and simulated streamflows for September-streamflows that depend, in part, on recharge prior to June-accounted for about 8 percent of the streamflows in March.

For Hop Brook subbasin, streamflows simulated in scenarios 3B and 3C for March with LID based on 100 -percent development of commercially zoned land were higher by 10 (scenario 3B) and 15 (scenario 3C) percent (table 6) than streamflows simulated without LID. For September, streamflows were higher with LID by 13 (scenario 3B) and 11 (scenario 3C) percent than without LID (table 6). These results show that the greater the area within Hop Brook subbasin where LID practices were applied, the less the development affected recharge and streamflow. LID practices applied to individual parcels of land can affect recharge in that parcel but have a small effect on streamflow out of the subbasin. If LID practices are applied to a greater number of surrounding parcels, the effect is additive with a correspondingly greater effect on streamflow. This result may be applicable to other subbasins as well.

The second category of comparisons included those of simulated streamflows for the various LID scenarios with combinations of 22 and 100 percent of available commercial land developed and both traditional (50 percent decrease in recharge) and LID (10 percent change in recharge) practices. These results were compared to the basecase streamflow (1997-2001) to show how a particular development practice could affect streamflow relative to streamflow from undeveloped land (table 6). March streamflows for traditional practices were lower than the undeveloped case by 3.3 to $0.26 \mathrm{ft}^{3} / \mathrm{s}$ (13 to 1.0 percent). Streamflow changes for LID practices ranged from -1.0 to $+0.97 \mathrm{ft}^{3} / \mathrm{s}(-3.8$ to +3.6 percent) compared to the basecase streamflow $\left(27 \mathrm{ft}^{3} / \mathrm{s}\right)$. September streamflow changes for traditional practices ranged from -0.22 to $+0.11 \mathrm{ft}^{3} / \mathrm{s}$ ( -10 to +5.1 percent), and changes for LID practices were less than $0.1 \mathrm{ft}^{3} / \mathrm{s}$ (1.5 to 3.2 percent) compared to the basecase streamflow $\left(2.1 \mathrm{ft}^{3} / \mathrm{s}\right)$. These comparisons show that most scenarios with LID practices generated an increase in streamflow for March and September compared to traditional (non-LID) practices.

One goal of LID is to lessen the effect of development on the natural ground-water system. The Hop Brook LID scenarios included LID applied to 920 acres of a 5,025-acre subbasin. The differences between individual LID scenario streamflows and the basecase streamflow ranged from -3.8 to +3.6 percent for March and from +1.5 to +3.2 percent for September; these outcomes are due to change-in-recharge characteristics unique to each scenario that resulted in streamflow values both lower and higher than the basecase streamflow. 


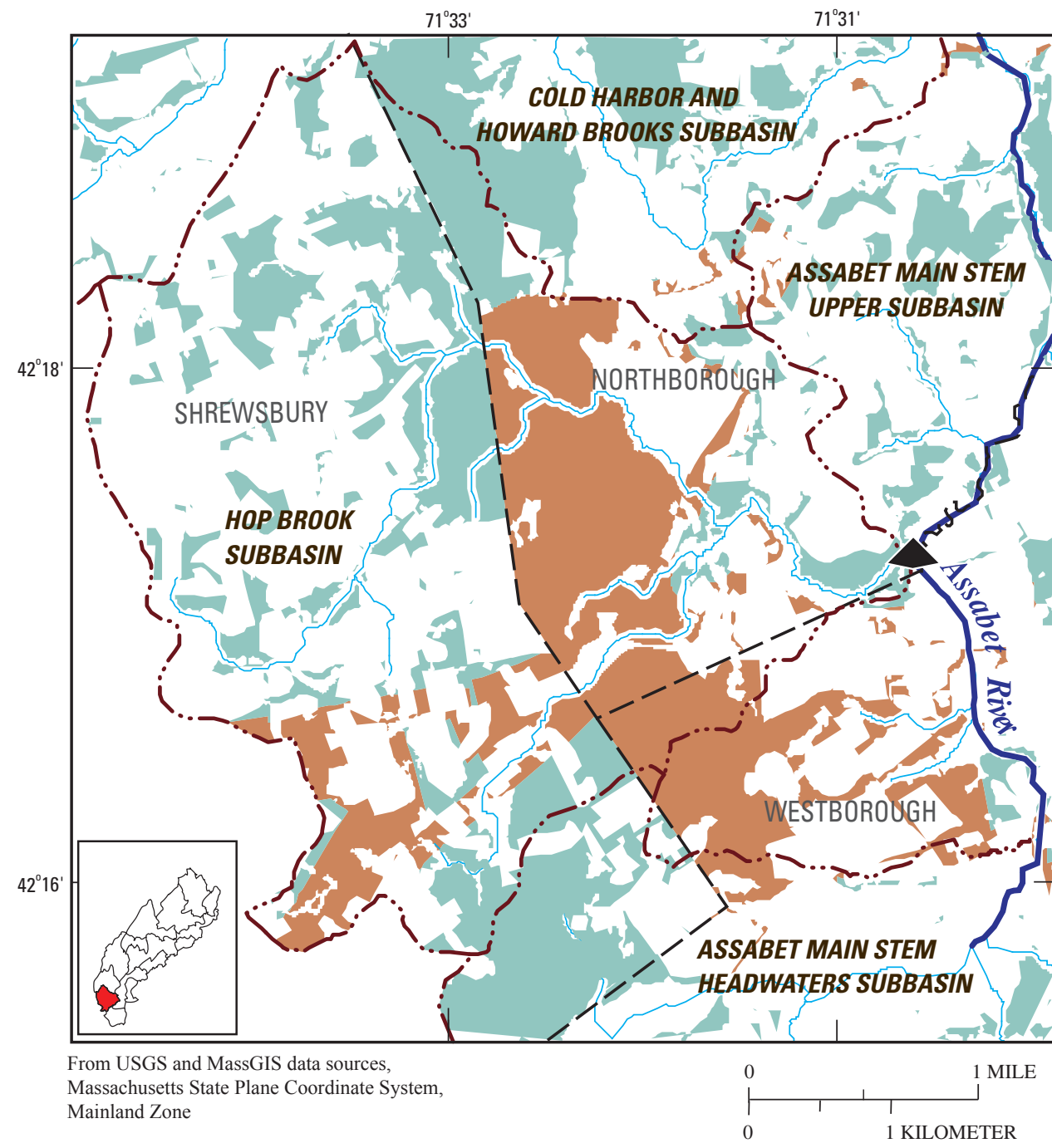

EXPLANATION

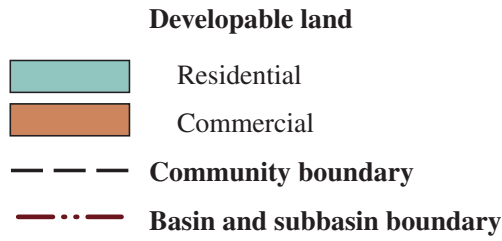

Points of subbasin streamflow comparison-Simulated basecase to scenario 2, 3A, 3B, 3C, 4A, 4B, and 4C with year 2030 water- and land-use conditions, and six Hop Brook LID scenarios

Figure 22. Areas of developable residential and commercial land using low-impact development (LID) practices, Hop Brook subbasin and vicinity, Assabet River Basin, eastern Massachusetts. 
Table 6. Change in simulated average monthly March and September base flow streamflow between areas of low-impact development (LID) and of traditional development and change between base flow simulated for two scenarios and basecase conditions, Hop Brook subbasin, Assabet River Basin, eastern Massachusetts.

$\left[\mathrm{ft}^{3} / \mathrm{s}\right.$, cubic feet per second; --, no data]

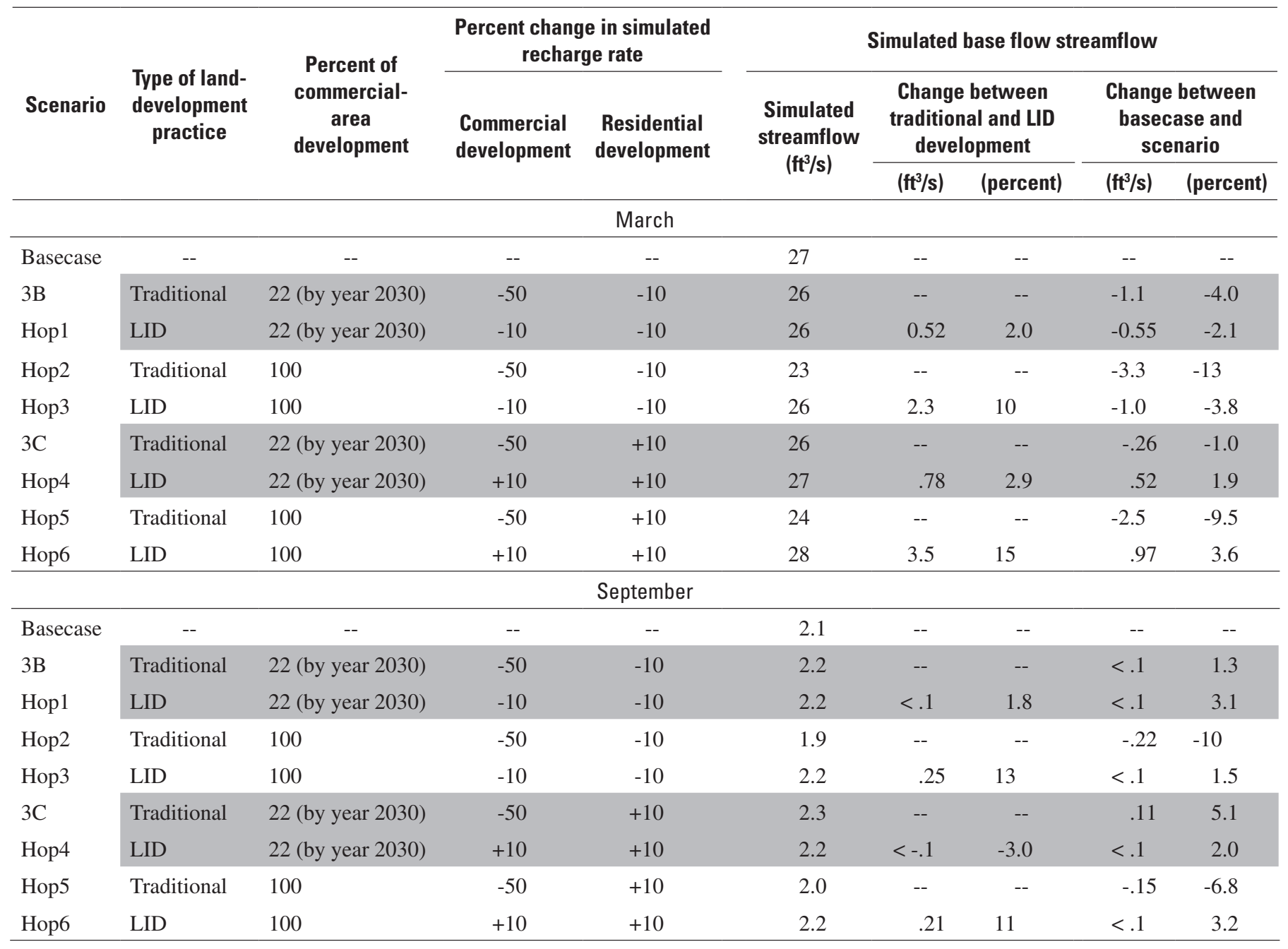


These are the simulated changes in streamflow that would occur if undeveloped land were developed by using simulated LID practices as defined in this study.

The following values illustrate the difference in streamflows when LID was used instead of traditional practices. In the Hop Brook subbasin (5,025 acres), simulated March and September streamflows were greater by as much as 2.9 and 1.8 percent, respectively, when 22 percent (203 acres) of the available commercial land (920 acres) was developed by using LID instead of traditional practices; and streamflows were greater by as much as 15 and 13 percent, respectively, when 100 percent of the available commercial land was developed by using LID instead of traditional practices. The rate of recharge from precipitation to the ground-water system most likely would be altered by development. Depending on the actual effects of LID practices, streamflows in the subbasin could increase or decrease by about 4 percent in March, and streamflows could increase by about 3 percent in September compared to streamflows for undeveloped land. These streamflow changes are smaller than the 15-percent change simulated for traditional land-development practices.

\section{Assessment of Potential Effects of Sewering in Fort Pond Brook Subbasin, Assabet River Basin-A Test Case}

The basecase (1997-2001) scenario for the Assabet River Basin ground-water model (DeSimone, 2004) did not include any sewered area in Acton because the Acton WWTF did not become operational until 2002 (fig. 23). The community of Acton was chosen as a test case because of the newly constructed WWTF, which discharges to ground water in the Assabet Main Stem Lower subbasin, and the availability of data for use in the simulations. Three different sewered areas were simulated to compare the effects of decreased return flow and increased WWTF discharge on streamflows in the Fort Pond Brook and Main Stem Lower subbasins. Basecase streamflows in the Main Stem Lower reach of the Assabet River are about 5 times greater in March and about 19 times greater in September than streamflows in Fort Pond Brook. Streamflow in Fort Pond Brook downstream from the three Acton sewered areas was also of interest. In the sewered areas, public-supply water that would have returned to the ground-water system as return flow through inflow from septic systems - mostly in the Fort Pond Brook subbasin, which encompasses most of the area of Acton-would now be routed to the discharge point for the Acton WWTF near the Assabet River in the Main Stem Lower subbasin (fig. 23). This effectively reduced inflow to the Fort Pond Brook subbasin (and consequently reduced streamflow in Fort Pond Brook itself) and increased inflow to the Main Stem Lower subbasin (and consequently increased streamflow in the Assabet River).
The Acton sewered-area scenarios were based on changes in the components of water use as simulated in scenario 2. The four scenarios that included the sewered areas and the projected WWTF discharge volumes used in this study are: (1) a basecase simulation consisting of no sewered area in Acton (to which the following three scenarios were compared); (2) scenario Acton-B, which included the current (2002) extent of the sewered area (fig. 23) of about 1,200 total acres and a year $2030 \mathrm{WWTF}$ discharge of $0.25 \mathrm{Mgal} / \mathrm{d}$; (3) scenario Acton-C, which included the current area and an additional area called potential-area A (fig. 23), which increased the modeled sewered area by about 173 acres for a total sewered area of about 1,373 acres and a year 2030 WWTF discharge of $0.29 \mathrm{Mgal} / \mathrm{d}$; and (4) scenario Acton-D, which included the current area, potential-area A, and another area called potential-area B (fig. 23), which increased the modeled sewered area by about 787 acres for a total sewered area of about 2,160 acres and a year 2030 WWTF discharge of $0.40 \mathrm{Mgal} / \mathrm{d}$. The return-flow volumes that corresponded to septic-tank return flow applied to those specific sewered areas in the basecase simulation were not included in the seweredarea scenarios because those volumes were instead routed to the WWTF. The predicted year 2030 discharge volumes for the Acton WWTF and the sewered areas (potential area-A and potential area-B) were provided by the Town of Acton (Brent L. Reagor, Deputy Director, Acton Health Department, written commun., 2007).

Streamflow comparisons for each Acton seweredarea scenario for March and September revealed decreased streamflows in Fort Pond Brook downstream from the sewered areas and increased streamflows in the Assabet River downstream from the Acton WWTF discharge point. The difference between the basecase streamflow and the simulated streamflow in Fort Pond Brook upstream from the various sewered areas in each of the Acton sewered-area scenarios was $0.1 \mathrm{ft}^{3} / \mathrm{s}$ for both March and September. The increase in streamflow at this point was due to increased return flow for year 2030 water use that was applied to upstream portions of Fort Pond Brook subbasin.

Simulated streamflows downstream from the sewered areas in Acton were compared at the point where Fort Pond Brook crosses the Acton and Concord town boundary (point 1; fig. 23). Simulated basecase streamflows from Fort Pond Brook were about $67 \mathrm{ft}^{3} / \mathrm{s}$ for March and $2.6 \mathrm{ft}^{3} / \mathrm{s}$ for September. Simulated March streamflows from the Acton sewered-area scenarios (Acton-B, Acton-C, and Acton-D) decreased from the basecase by $0.3,0.3$, and $0.4 \mathrm{ft}^{3} / \mathrm{s}$, respectively (all less than 0.6 percent). September streamflows decreased from the basecase by $0.2,0.2$, and $0.3 \mathrm{ft}^{3} / \mathrm{s}$ $(6.3,9.2$, and 15 percent $)$, respectively. Changes in simulated streamflow in Fort Pond Brook due to the simulated sewered areas were greater for September.

Basecase streamflows in the Assabet River Main Stem Lower subbasin were about $328 \mathrm{ft}^{3} / \mathrm{s}$ for March and $50 \mathrm{ft}^{3} / \mathrm{s}$ for September. Changes in simulated streamflow from the basecase for the Acton sewered-area scenarios 


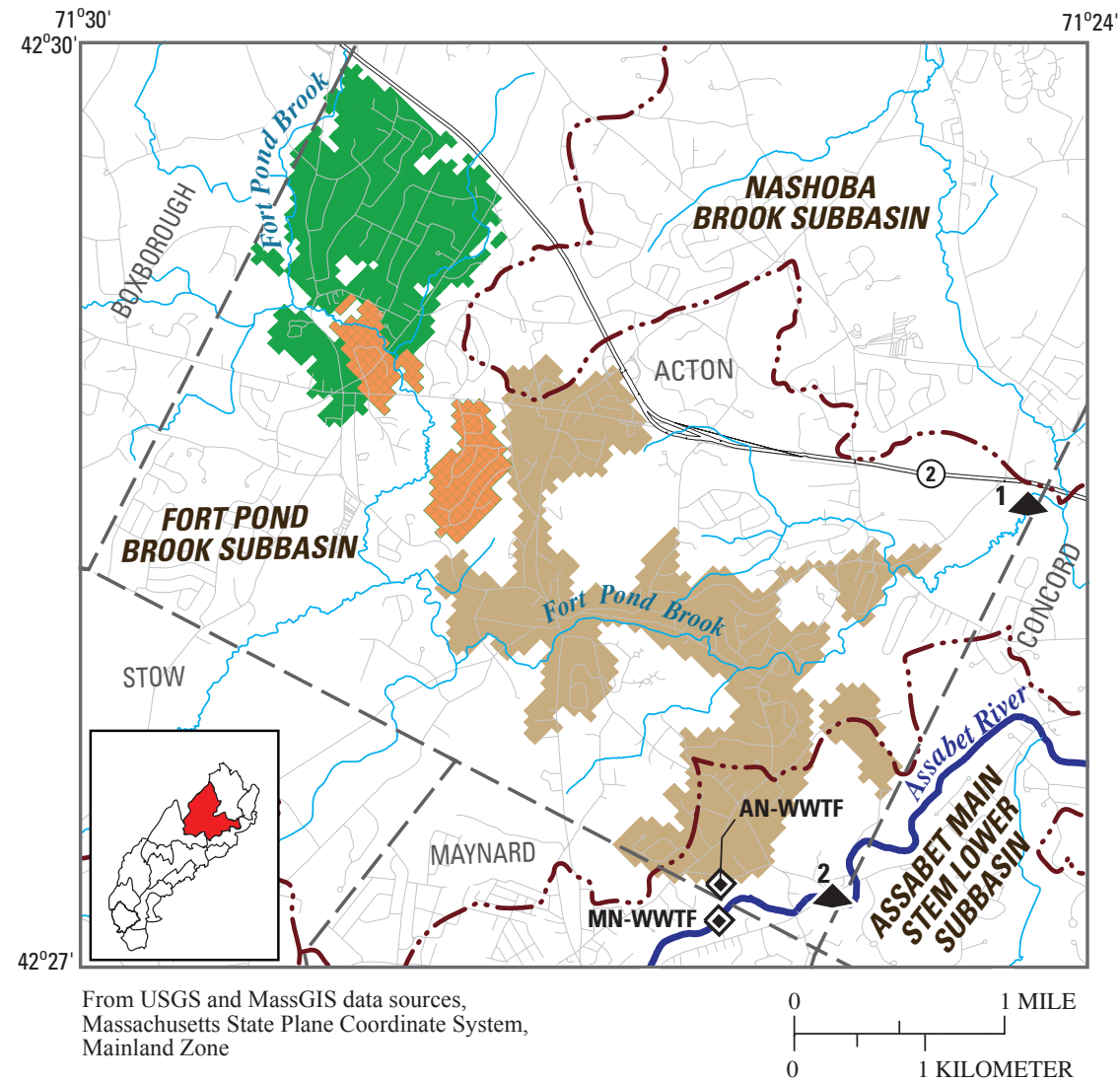

EXPLANATION



Figure 23. Acton sewered areas, areas of potential sewering, and wastewatertreatment facility discharge points, Fort Pond Brook subbasin, Assabet River Basin, eastern Massachusetts.

(Acton-B, Acton-C, and Acton-D) in the Assabet River downstream of the Acton WWTF (point 2; fig. 23) were increases of less than 0.8 percent for March $(2.3,2.4$, and $2.5 \mathrm{ft}^{3} / \mathrm{s}$, respectively), and less than 3.4 percent for September $\left(1.6,1.6\right.$, and $1.8 \mathrm{ft}^{3} / \mathrm{s}$, respectively). These increases in streamflows in the Assabet River downstream from the Acton WWTF were small compared to total average annual streamflow. Simulated effects of the Acton sewered area were confined mostly to streamflow decreases in Fort Pond Brook within and downstream from the sewered areas and streamflow increases in the Assabet River downstream from the Acton WWTF. Downstream from the confluence of Fort Pond Brook and the Assabet River, simulated streamflow changes from basecase were minimal. However, decreased simulated streamflow in the lower portion of Fort Pond Brook may be of greater importance than increased streamflow in the Assabet River. The simulation result of potential decreased streamflow downstream from expanded sewered areas in the Fort Pond Brook subbasin may occur in other subbasins if sewered areas are similarly expanded. 


\section{Summary}

Future changes in water use and land use may affect the magnitude of streamflows in areas of the Interstate-495 region in eastern Massachusetts. The purpose of this study, completed by the U.S. Geological Survey (USGS) in cooperation with the Metropolitan Area Planning Council (MAPC), was to evaluate future streamflows by using water- and land-use scenarios with data projected for the year 2030. The data were applied to two existing USGS ground-water models for the Interstate-495 region in the Assabet and Upper Charles River Basins. Streamflows that resulted from each of seven scenarios were compared on a subbasin scale to basecase streamflows that represented present (1997-2001 for the Assabet River Basin and 1989-1998 for the Upper Charles River Basin) conditions.

The bases for comparisons made in this study were results of ground-water-model simulations for three categories of projected year 2030 water and land use, which were defined in consultation with the Technical Advisory Committee composed of representatives from Federal agencies, communities, and other organizations. Scenarios included 2030 water use, 2030 land use, and a combination of 2030 water use and 2030 land use. Year 2030 water use for the scenarios included withdrawals for public supply, areal return flows in areas of public supply and private septic systems, consumptive use in areas of private supply and private septic systems, and wastewater-treatment-facility (WWTF) discharges.

Year 2030 water use was projected for communities in the Assabet and Upper Charles River Basins by MAPC. Publicsupply water demand for 2030 from in-basin sources was projected to increase for both the Assabet and Upper Charles River Basins. Basecase demand from in-basin sources was 9.39 and 9.51 Mgal/d for the Assabet and Upper Charles River Basins, respectively. Year 2030 demand from in-basin sources was projected to be about 14 percent greater $(10.72 \mathrm{Mgal} / \mathrm{d})$ for the Assabet River Basin and about 25 percent greater (11.90 Mgal/d) for the Upper Charles River Basin. The current and proposed supply wells simulated with the basecase ground-water models for both basins were estimated to be able to meet projected 2030 demand; however, some of the supply wells were coded to withdraw at or near the State-permitted limits for some months of the year.

All land in the study area that could be developed at some point in the future (developable land) was identified by MAPC for the Assabet and Upper Charles River Basins. Land-use comparisons revealed that low-density residential land-use was projected for 81 percent of the developable land in each basin. Commercial land use was projected for 16 percent of the Assabet River Basin and 17 percent of the Upper Charles River Basin. Less than 3 percent of the remaining developable land in both river basins was projected to be developed for medium- and high-density residential use. Assessment of current undeveloped land use (forested or open) and underlying geology (till or sand and gravel) revealed that 79 percent of the developable land in the Assabet River Basin and 83 percent of the developable land in the Upper Charles River Basin is currently (1999) forested. Till underlies 73 percent of the developable land in the Assabet River Basin and 62 percent in the Upper Charles River Basin.

Conversion of undeveloped forested land to low-density residential development is the most common type of landuse conversion associated with suburban development within the Assabet and Upper Charles River Basins. For example, if currently open land is developed for residential use, recharge would likely decrease, and in contrast, if currently forested land is developed for residential use, recharge could decrease or increase. This potential change was accommodated by the use of two alternative estimates of change in residentialarea recharge in the scenarios incorporating projected 2030 land-use change. The first alternative (in scenarios 3B and 4B) assigned a change of -10 percent of the basecase recharge to undeveloped land undergoing residential development, whereas the second (in scenarios 3C and 4C) assigned a change of +10 percent. These alternatives served to bracket the possible changes in recharge rates that could occur owing to the uncertainty of future development and the resulting effects on estimates of 2030 streamflow in the scenarios that incorporated land-use change. This uncertainty was greatest in the subbasins projected to have the greatest degree of residential development and was generally greater in the tributary and headwaters subbasins than in the main-stem subbasins. For example, in the Mill River subbasin of the Upper Charles River Basin, water use alone (scenario 2) caused a decrease in streamflow of 7.8 percent, and land use alone caused a decrease of 2.6 percent (scenario 3B) and an increase of 1.9 percent (scenario 3C). When 2030 water-use and land-use changes were combined, along with the variation in recharge for residential-area development, the declines in streamflow from Mill River subbasin were variable. For example, a decrease in recharge of 10 percent for residential development (scenario 4B) caused an 11-percent decline in streamflow, whereas an increase of 10 percent in recharge for residential development (scenario 4C) caused a decline of only 5.9 percent. These results for the Mill River subbasin show that streamflow declines are greater when 2030 water use is combined in a subbasin with a decrease in recharge; however, an offsetting effect results when 2030 water use is combined with an increase in recharge. The current use (forest or open) of land to be developed is important with respect to the magnitude of resulting streamflow changes, whether or not water use changes (for example, pumping for public supply increases) in the subbasin. The results of these simulations may be applicable to similar valley-fill aquifer systems in the glaciated northeastern United States.

The effect on streamflow of increasing the extent of sewer lines and the corresponding reduction in return flow from septic systems in a subbasin was simulated for Fort Pond Brook subbasin in the Assabet River Basin. Three sewered areas of increasing extent (1,200, 1,373, and 2,160 acres) were modeled. The corresponding changes in simulated 
streamflow from basecase streamflows were decreases of up to 0.6 percent for March and decreases of up to 15 percent for September. Extending sewer lines in Fort Pond Brook subbasin had the greatest effect on September streamflows. The simulation result of potential decreased streamflow downstream from expanded sewered areas in the Fort Pond Brook subbasin may occur in other subbasins if sewered areas are similarly expanded.

Changes in land use had the greatest effect on streamflows in the spring months because land-use changes directly affect aquifer-recharge rates, which are more important in the spring than in the summer. Year 2030 commercial land use was represented in the scenarios by a decrease of 50 percent in natural recharge. Low-Impact Development (LID) scenarios were simulated for Hop Brook subbasin of the Assabet River Basin; instead of a decrease of 50 percent in recharge (traditional practice) for commercial areas, a decrease of 10 percent (LID practice) was used. When 100 percent (920 acres) of the developable commercially zoned land was used with LID practices (as defined in this study), simulated streamflows from Hop Brook subbasin for March were higher by up to 15 percent, and for September by up to 13 percent, than streamflows simulated with traditional practices. In this simulation, the greater the area where low-impact development practices were applied, the less was the overall effect of development on recharge and nonstorm streamflow compared to the effects of traditional development practices for commercial areas. LID practices applied to individual parcels can potentially increase recharge in these parcels and consequently produce a small increase in nonstorm streamflow out of the subbasin compared to lower recharge and nonstorm streamflows usually associated with traditional development practices in commercial areas. If lowimpact development (as defined in this study) is applied to a greater number of surrounding parcels, however, the increase in recharge is additive, with a correspondingly greater increase in nonstorm streamflow out of the subbasin compared to the effects on recharge and nonstorm streamflow associated with traditional development practices. This result may be applicable to other subbasins in the glaciated northeast as well.

Changes in water use and wastewater return flow generally have the greatest effects in the summer months when streamflow and aquifer-recharge rates are low and water use is high. Increases in simulated main-stem streamflow in September were due mainly to increased discharge of treated effluent from WWTFs on the main-stem river. The quality of water downstream from WWTF discharge locations can affect fish and other aquatic species. For both the Assabet and Upper Charles River Basins in March, the proportion of simulated 2030 streamflow consisting of treated WWTF effluent differed by less than 2 percent from that in the basecase streamflow. The proportion of streamflow consisting of WWTF effluent in September was slightly more variable for both river basins than in March. In the Assabet River Basin in September, the average percentages of wastewater effluent in simulated streamflow for all seven scenarios were 60,36 , and 22 percent of model-calculated streamflow from the Assabet Main Stem Upper, Middle, and Lower subbasins, respectively; the September basecase percentages to which the scenario results were compared were 55, 32, and 20 percent, respectively. In the Upper Charles River Basin in September for each scenario, wastewater accounted for an average of 16 percent of model-calculated streamflow for the Main Stem West subbasin and 22 percent for the Main Stem East subbasin. The basecase values for wastewater were 14 percent for the Main Stem West and 18 percent for the Main Stem East subbasins. In the Assabet River Basin, WWTF discharge accounted for a greater proportion of main-stem simulated streamflow in the Upper subbasin than in the Lower subbasin; that is, WWTF discharge becomes a lower proportion of total streamflow with distance downstream. In contrast, WWTF discharge in the Upper Charles River Basin accounted for a greater proportion of simulated streamflow in the Main Stem East subbasin than in the West subbasin; that is, WWTF discharge becomes a greater proportion of streamflow with distance downstream. This may be due to the distribution of wastewater discharges along the main stem of the river. In the Assabet River, the largest of four discharges is near the headwaters, whereas in the Upper Charles River, the largest of two discharges is near the end of the model area. However, the proportion of simulated streamflow that consists of simulated WWTF discharge at the mouth of each river basin is the same for both the Assabet and Upper Charles River Basins-about 22 percent. These differences show the varied localized effects that WWTF discharge has on streamflows among and within river basins.

In the Assabet River Basin, average annual streamflow changes were comparatively small-for all scenarios and subbasins, the average decrease in streamflows was $0.18 \mathrm{ft}^{3} / \mathrm{s}$, and the average increase in streamflows was $0.14 \mathrm{ft}^{3} / \mathrm{s}$. For the Upper Charles River Basin, changes in average annual streamflow were greater than those for the Assabet River Basin; for all scenarios and subbasins, the average decrease in streamflows was $0.69 \mathrm{ft}^{3} / \mathrm{s}$, and the average increase in streamflows was $0.39 \mathrm{ft}^{3} / \mathrm{s}$. This difference could be due in part to the increase in year 2030 water use (scenario 2), which typified most of the scenario streamflow changes in the Upper Charles River Basin.

The effects of year 2030 land- and water-use change on streamflows in the Assabet River Basin depended upon the time of year, the hydrologic position of the subbasin in the larger basin, and the amount of new commercial and residential development projected for a subbasin. Model simulations indicated that the greatest percent decreases in streamflow (up to 76 percent in one subbasin), compared to the basecase, can be expected to occur in September when streamflows are naturally at their lowest level. By contrast, simulated March streamflows had decreases of less than 6.5 percent from basecase streamflows for all subbasins and scenarios. 
The effects of land-use and water-use changes appear to be greatest in the headwaters and small tributaries of the large river systems. In the Assabet River Basin, the largest September percent decreases in simulated streamflow occurred in tributary and headwater subbasins. For example, simulated streamflows from Fort Meadow Brook, Cold Harbor and Howard Brooks, and the Assabet Main Stem Headwaters subbasins decreased 76, 20, and 17 percent, respectively. These large decreases can be attributed to year 2030 changes in either water use (scenario 2) or water use and land use combined (scenario 4B). Although changes in land use alone (scenario 3A, B) caused simulated streamflow to decrease in 8 of the remaining 12 subbasins, in only one case was the decrease greater than 5 percent (Danforth Brook, 7.4 percent). In addition, September streamflow decreases in the Main Stem Assabet subbasins (Upper, Middle, and Lower) were all relatively small (less than 5 percent). The modest response of the main-stem subbasins to projected development likely reflects the fact that depletion from increased withdrawals is offset by augmentation from increased wastewater discharge to the main stem and by inflows from upstream subbasins, as well as the relatively small amount of developable land in the main-stem Assabet River corridor in comparison to developable land in the tributary subbasins.

The effects of year 2030 water and land use on streamflows in the Upper Charles River Basin also differed by subbasin, depending upon season, hydrologic position, and projected basin-specific water- and land-use patterns, but increased water use contributed to streamflow decreases in most subbasins. Changes in simulated streamflows in March for year 2030 in the Upper Charles River Basin were within \pm 6 percent of the basecase for all scenarios and subbasins. Decreases in simulated streamflows by percentage for September in 2030 were greater than decreases in March but less than the September decreases for some of the subbasins in the Assabet River Basin. Only two subbasins in the Upper Charles River Basin had projected decreases greater than 5 percent (11 percent for Mill River subbasin and 6.6 percent for Mine Brook subbasin, both in scenario 4B). When increased water use is combined with land-use changes in a subbasin, streamflows can be affected. The degree of effect is variable and depends on the acreage, current use of the land to be developed, and the type of development projected to occur.

No particular scenario caused the same effect in all subbasins. Streamflow changes depend on the manner in which each subbasin is affected by the particular pattern of 2030 land use and water use projected for that subbasin. The streamflow changes summarized in this report (table 3 for the Assabet River Basin and table 5 for the Upper Charles River Basin for both March and September) could be used by water managers to assess the potential year 2030 changes to which the local subbasin is most sensitive and to determine whether those potential changes are important to local or state goals or regulatory limits.

\section{References Cited}

Armstrong, D.S., Richards, T.A., and Parker, G.W., 2001, Assessment of habitat, fish communities, and streamflow requirements for habitat protection, Ipswich River, Massachusetts, 1998-99: U.S. Geological Survey Water-Resources Investigations Report 01-4161, 72 p.

Barlow, P.M., 1997, Dynamic models for conjunctive management of stream-aquifer systems of the glaciated northeast: Storrs, Conn., University of Connecticut, Ph.D. thesis, $256 \mathrm{p}$.

Barlow, P.M., and Dickerman, D.C., 2001, Numericalsimulation and conjunctive-management models of the Hunt-Annaquatucket-Pettaquamscutt stream-aquifer system, Rhode Island: U.S. Geological Survey Professional Paper 1636, 79 p.

Bent, G.C., 1995, Streamflow, ground-water recharge and discharge, and characteristics of surficial deposits in Buzzards Bay Basin, southeastern Massachusetts: U.S. Geological Survey Water-Resources Investigations Report 95-4234, 56 p.

Bent, G.C., 1999, Streamflow, base flow, and groundwater recharge in the Housatonic River Basin, western Massachusetts and parts of eastern New York and northwestern Connecticut: U.S. Geological Survey Water-Resources Investigations Report 98-4232, 68 p.

DeSimone, L.A., 2004, Simulation of ground-water flow and evaluation of water-management alternatives in the Assabet River Basin, Eastern Massachusetts: U.S. Geological Survey Scientific Investigations Report 2004-5114, $133 \mathrm{p}$.

DeSimone, L.A., Walter, D.A., Eggleston, J.R., and Nimiroski, M.T., 2002, Simulation of ground-water flow and evaluation of water-management alternatives in the Upper Charles River Basin, eastern Massachusetts: U.S. Geological Survey Water-Resources Investigation Report 02-4234, 94 p.

Eggleston, J.R., 2004, Evaluation of strategies for balancing water use and streamflow reductions in the Upper Charles River Basin, Eastern Massachusetts: U.S. Geological Survey Water-Resources Investigations Report 03-4330, 85 p.

Harbaugh, A.W., Banta, E.R., Hill, M.C., and McDonald, M.G., 2000, MODFLOW-2000, the U.S. Geological Survey modular ground-water model-User guide to modularization concepts and the ground-water flow process: U.S. Geological Survey Open-File Report 00-92, 121 p. 
MassGIS, 1997, MassGIS datalayer descriptions and guide to user services: Boston, Mass., Commonwealth of Massachusetts, Executive Office of Environmental Affairs, $131 \mathrm{p}$.

MassGIS, 2001, MassGIS datalayer descriptions and guide to user services: Boston, Mass., Commonwealth of Massachusetts, Executive Office of Environmental Affairs, $214 \mathrm{p}$.

MassGIS, 2006, Zoning Datalayer Description page: accessed January 31, 2006, at http://www.mass.gov/mgis/zn.htm

Parker, G.W., Armstrong, D.S., and Richards, T.A., 2004, Comparison of methods for habitat protection at selected sites on the Assabet and Charles Rivers, eastern Massachusetts: U.S. Geological Survey Scientific Investigations Report 2004-5092, 72 p.

Prudic, D.E., 1989, Documentation of a computer program to simulate stream-aquifer relations using a modular, finitedifference, ground-water flow model: U.S. Geological Survey Open-File Report 88-729, 113 p.

Zarriello, P.J., and Ries, K.G., III, 2000, A precipitation-runoff model for analysis of the effects of water withdrawals on streamflow, Ipswich River Basin, Massachusetts: U.S. Geological Survey Water-Resources Investigations Report 00-4029, 99 p. 


\section{Appendix 1. Methods Used to Develop Input Files for 2030 Model Scenarios}

\section{Contents}

Estimation of 2030 Monthly Withdrawal Rates for Public Water Supplies ............................47

Estimation of 2030 Consumptive Use and Return-Flow Rates .................................................51

Estimation of 2030 Recharge Rates ...............................................................................58

Description of 2030 Simulation Model.................................................................................61

\section{Figures}

1-1. Graphs showing factors representing the percentage difference of total monthly demand from annual average demand for (A) January 1997 through December 2001 for communities in the Assabet River Basin, (B) January 1989 through December 1998 for communities in the Upper Charles River Basin, and (C) total average demand ........50

1-2-1-5 Maps showing-

1-2. Locations of production wells, discharges from municipal and nonmunicipal wastewater-treatment facilities (WWTF), surficial geology, and Acton sewered area in (A) Assabet and (B) Upper Charles River basins, eastern Massachusetts.

1-3. Areas of potential return flow (year 2030) from developable land in (A) Assabet and $(B)$ Upper Charles River Basins, eastern Massachusetts

1-4. Areas of potential consumptive water use (year 2030) in (A) Assabet and (B) Upper Charles River Basins, eastern Massachusetts.

1-5. Monthly recharge rates used in model simulations for (A) Assabet and (B) Upper

Charles River Basins, eastern Massachusetts. .62

\section{Tables}

1-1. Percentage of community area, total population, population using public water, and simulated water demand for basecase conditions and year 2030, by subbasin, Assabet and Upper Charles River Basins, eastern Massachusetts.

1-2. Simulated recharge rates, by land use and surficial geology, Upper Charles River Basin, eastern Massachusetts

1-3. Change in recharge rates from basecase conditions due to change in land use and magnitude of year 2030 land-use change, by surficial geology, Assabet and Upper Charles River Basins, eastern Massachusetts.

1-4. Change in recharge rate for acres to be developed by year 2030 for residential and commercial uses, by surficial geology, in subbasins in the Assabet and Upper Charles River Basins, eastern Massachusetts

1-5. Recharge rates for basecase conditions and rates using 10 and 50 percent of basecase, by surficial geology, Assabet and Upper Charles River Basins, eastern Massachusetts.

1-6. Average annual steady-state water budgets for the ground-water flow system for basecase and seven scenarios, Assabet River Basin, eastern Massachusetts. 


\section{Tables-Continued}

1-7. Average annual steady-state water budgets for the ground-water flow system for basecase and seven scenarios, Upper Charles River Basin,

eastern Massachusetts

1-8. Water budgets for March and September for the ground-water flow system for basecase and seven scenarios, Assabet River Basin, eastern Massachusetts.

1-9. Water budgets for March and September for the ground-water flow system for basecase and seven scenarios, Upper Charles River Basin, eastern Massachusetts 